
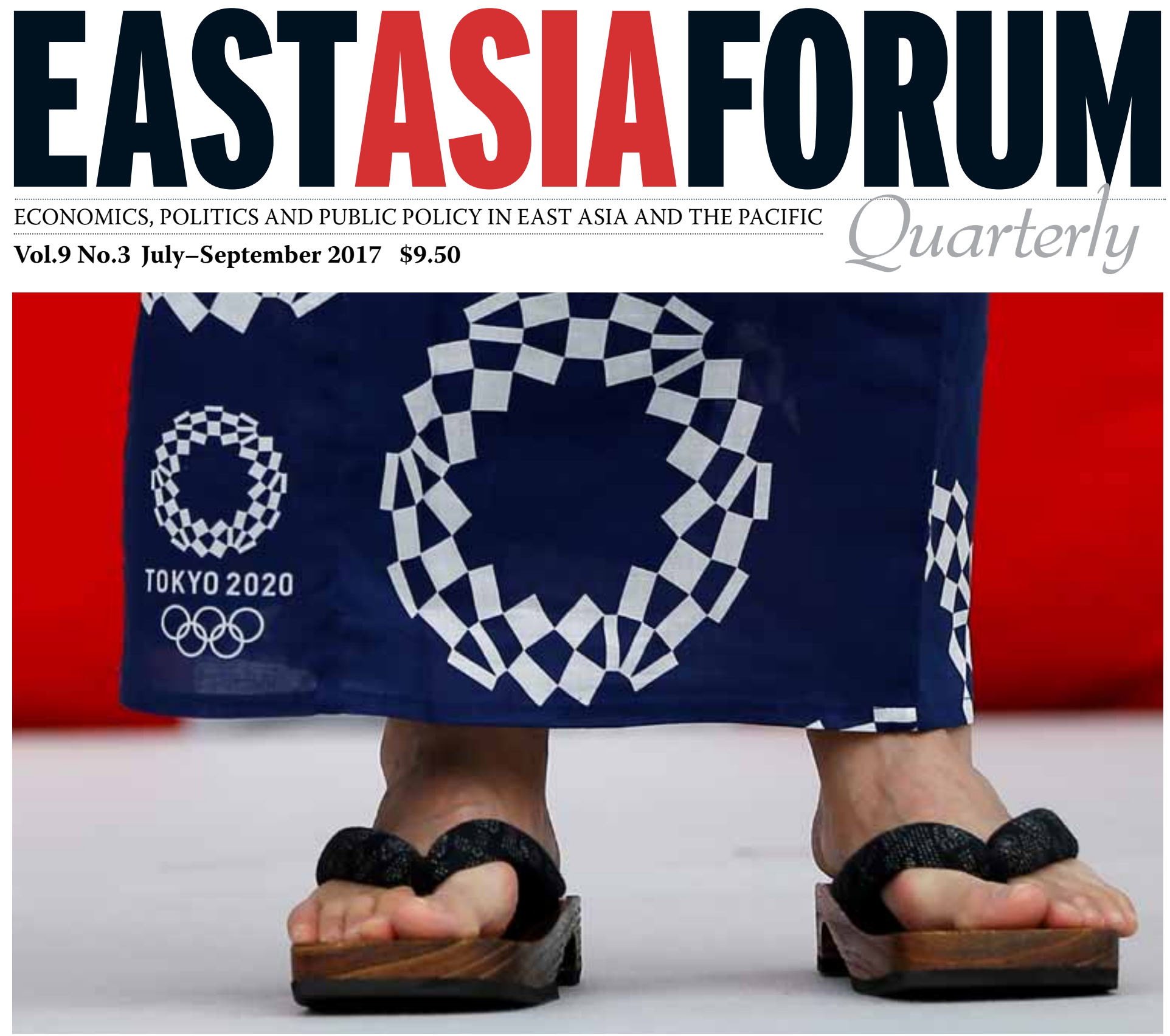

\title{
Japan repositions
}

Fumiaki Kubo Trump prompts cautious shift to self-reliance

Kimie Iwata Empowering women: personal gain, corporate rewards

Yoichi Funabashi and Harry Dempsey Japan and China move closer

Yukinobu Kitamura Economy pushes Abe towards his endgame

Gerald Curtis Abe's charm offensive ... and more 


\section{EASTASIAFORUM \\ Quarterly \\ ISSN 1837-5081 (print) \\ ISSN 1837-509X (online)}

\section{From the Editors' desk}

Japan is repositioning. Domestically, with the collapse of his electoral support base, Prime Minister Shinzo Abe no longer looks like Teflon man. He has not been able to shake off scandals around what appear to be special deals for friends, while the ruling Liberal Democratic Party (LDP) suffered a major loss to Governor of Tokyo Koike Yuriko in the Tokyo Metropolitan Assembly election in July. Yet the main opposition to the LDP at the national level, the Democratic Party, remains in tatters, its future uncertain.

If Abe is to survive until the Olympics in 2020, he will have to be seen to make progress soon on difficult economic reforms. His tenure as prime minister since 2012 has brought political stability and a sense of leadership but he is yet to make a dent in the big structural issues of an ageing and shrinking population, rising inequality and rising government debt.

The external environment in which Japan finds itself has suddenly become more unpredictable and fluid than at any time since World War II. Dealing with a rising China is hard enough given the icy political relationship between the two countries, but the election of President Donald Trump has brought a new uncertainty to the US regional and global position, and to the international institutions and the rules-based order upon which Japan has relied. The escalating rhetoric from Trump and North Korea's Kim Jong-un threatens peace in Northeast Asia, with the development of North Korea's nuclear weapons program now a real threat to Japan.

This issue of East Asia Forum Quarterly examines key aspects of how Japan is repositioning on these and other issues and what has to be done.

Abe's adept diplomacy saw initial success in creating a close personal and working relationship with President Trump. But the growing uncertainty from Trump's America has shown Abe's deep pragmatism in what might be the first signs of his pivot to repair relations with China.

At home, Abe has put the empowerment of women on the agenda. Some progress has been made but it's still the case that for many women the choice between children and career is too heavily constrained by institutional and policy failure. For a country which is yet to grapple with immigration front-on, social attitudes will have to change if the potential for women and immigrants to revive Japanese society and its economy are to be fulfilled.

In Asian Review we cover what to do about the next Asian financial crisis, the Chinese view on North Korea, US strategy in the South China Sea and the political future of India's Narendra Modi.

\section{Shiro Armstrong and Amy King}

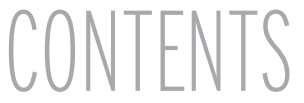

\section{FUMIAKI KUBO}

Trump prompts cautious shift to selfreliance

\section{YOICHI FUNABASHI AND HARRY DEMPSEY}

Trump threat drives Japan and China closer

\section{YUKINOBU KITAMURA}

Economy pushes Abe towards his endgame

\section{KIMIE IWATA}

Empowering women: personal gain, corporate rewards

13 BARRY STERLAND

ASIAN REVIEW: How is East Asia placed to avoid financial crises?

\section{AMITENDU PALIT}

ASIAN REVIEW: Modi's three years: cheers and challenges

19 MICHAEL MCDEVITT

ASIAN REVIEW: The South China

Sea seven years on

\section{CHEN DONGXIAO}

ASIAN REVIEW: Shifting the momentum on the Korean peninsula

\section{KRISTIN VEKASI}

Can business sell a likeable Japan to China?

\section{YUKI TATSUMI}

The costs of constitutional reform in Japan

\section{ERIKO SUZUKI}

Can Japan accept itself as a nation of immigrants?

\section{GERALD CURTIS}

Trump enamoured by an Abe charm offensive

COVER: Ready to step into the future. Tokyo Olympics 2020 emblems adorn this yukata, a casual summer kimono, worn at a ceremony in Tokyo marking the countdown to the Summer Games. PICTURE: ISSEI KATO, REUTERS. 


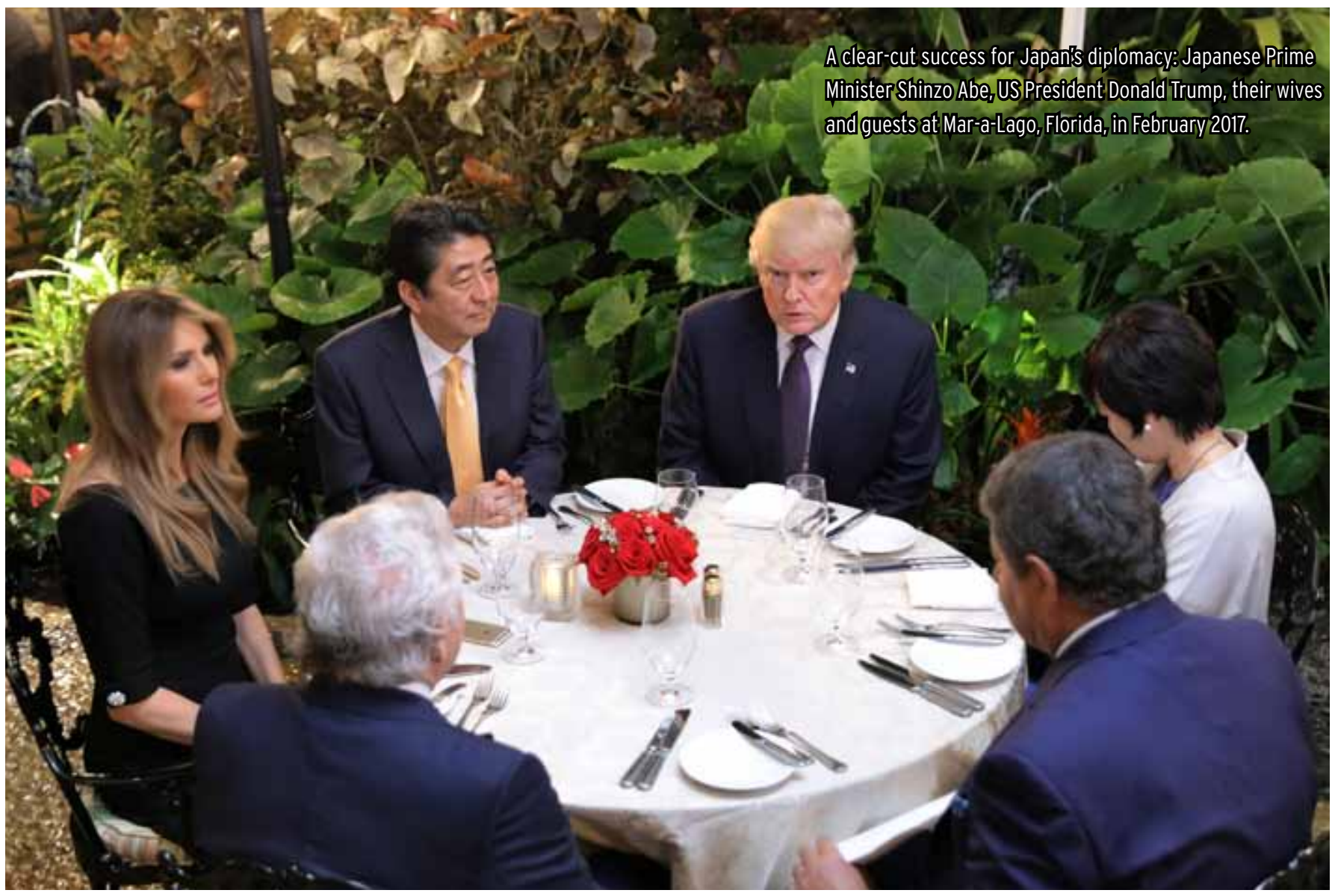

\section{Trump prompts cautious shift to self-reliance}

\section{FUMIAKI KUBO}

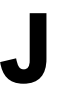

APAN was stunned and alarmed on 9 November 2016 to find that Donald Trump would be the next president of the United States.

During the presidential campaign, Trump had expressed a very different view of Japan from those of his predecessors. He argued that the current Japan-US Security Treaty was unfair because the United States alone was obliged to defend Japan, while Japan was under no obligation to defend America. Trump urged Japan to take charge of its own defence, including arming itself with nuclear weapons.

In an interview with The Washington Post, when it was pointed out that Japan and South Korea shouldered more than 50 per cent of the cost of US military bases (excepting personnel costs) in their countries, Trump asked why it wasn't 100 per cent. The US Department of Defense has estimated that up to 75 per cent of the cost of US forces in
Japan is offset by Japanese financial support.

When he was asked about the Senkaku/Diaoyu islands, Trump replied: 'I don't like to tell you what I'd do, because I don't want to'.

The Trump victory made it imperative for Japan to think seriously about how it could maintain a united front with the United States on national security matters.

The isolationist US candidate's victory happened precisely when Japan faced its most serious national security 


\section{EASTASIAFORUM reareterty} EDITORIAL STAFF

\section{Issue Editors}

Shiro Armstrong is Co-director, Australia-Japan Research Centre, and Editor of East Asia Forum, Crawford School of Public Policy, ANU.

Amy King is a Senior Lecturer in the Strategic and Defence Studies Centre, ANU, and a member of the East Asia Forum editorial board.

\section{Series Editors}

Peter Drysdale, Head, East Asia Forum and East Asian Bureau of Economic Research at the Crawford School of Public Policy, ANU.

Shiro Armstrong, Crawford School, ANU.

\section{Editorial Staff}

Coordination: Sam Hardwick.

Editing: Rosa Bishop, Alison Darby, Oliver Friedmann, Hannah Harmelin, Sam Hardwick, Nick Horton, Nishanth Pathy, Michael Wijnen, ANU.

Editorial Advisers: Peter Fuller, Max Suich.

Production: Peter Fuller, Words \& Pics. Original design: Peter Schofield.

Email Peter.Drysdale@anu.edu.au, Shiro.Armstrong@anu.edu.au.

The views expressed are those of the individual authors and do not represent the views of the Crawford School, ANU, EABER, EAF, or the institutions to which the authors are attached.

\section{ANU PRESS}

Published by ANU Press The Australian National University Canberra ACT 2601, Australia

Email: anupress@anu.edu.au Web: http://press.anu.edu.au crisis since the end of World War II-a turning point in its own defence policy. China had been challenging control and sovereignty over the Senkaku/Diaoyu islands since 2008, a threat that became more serious and more constant in 2010. Japan had never experienced a situation like this in the postwar period, with another country threatening to take by force territory it believes to be Japanese.

Apart from Trump's rhetoric on Japan during the campaign, three aspects of the 2016 election cycle indicated how politics might be developing in the United States.

First, Trump was the first nominee of a major US political party since World War II to have neither political nor military experience. This indicates the strength of voter anger and distrust towards today's career politicians and governing elite.

Second, as far as his promises and remarks during the campaign were concerned, Trump was the Republican Party's first isolationist nominee since before World War II.

Third, both Trump and the Democratic nominee, Hillary Clinton, took protectionist stances-another postwar first-and opposed the TransPacific Partnership to which Japan had given its support.

These might just have been coincidences, but they also suggest that US politics has been undergoing a sea change.

Trump captured the Republican nomination by taking a different position from former nominees on three important issues. His strong rhetoric on illegal immigrants was one major difference from his predecessors, including John McCain and George W Bush. His break with Republican orthodoxy on trade was more stark. And Trump's isolationist utterances have made him a rarity

\section{It would be smart for}

\section{Japan to try to do a}

lot more for its own

self-defence-including

spending more

among Republican presidential hopefuls, not to mention former presidential nominees.

More ominous for US allies is that Trump has proven that there is a path to party nomination on these policy lines.

Given that 17 candidates sought the Republican Party nomination, Trump's win could have been a fluke. But what if there is another candidate with similar policy views on illegal immigrants, trade and foreign policy in 2020, 2024 or 2028-one with a more intellectually developed position and with better command of policy details?

The mere thought of these possibilities makes Japan anxious about its future.

Post-election, the challenges for Japan were twofold: to deal with President Trump, with all his unpredictability; and to prepare quietly for the future direction of US foreign, national security and trade policies and their implications for Japan.

On the first challenge, the Japanese prime minister's office had succeeded in establishing a back channel with the Trump campaign which allowed Prime Minister Shinzo Abe to secure an informal meeting with Trump as early as 17 November 2016. This was followed by the official summit 
between the two leaders in February

2017.

Of vital importance to Japan, President Trump officially committed to defending the Senkaku/Diaoyu islands. Whether he would opt to maintain a line established by President Obama became a litmus test of Trump's foreign policy on Japan and, indeed, of his alliance diplomacy in general.

Overturning that commitment would have thrown the Japan-US alliance into a major crisis and shaken the foundations of all America's alliance relationships. Sooner or later, China would have ramped up its provocations in the area around the islands.

Abe's meeting with Trump was a rare clear-cut success for Japan's diplomacy. Tokyo got almost everything it wanted, including a clear commitment from the United States to apply Article 5 of the US-Japan Security Treaty to the Senkaku/Diaoyu islands, securing US military support in the event of an armed attack against Japan. Trump also issued a public statement of appreciation for Japan hosting US troops.

It was also reassuring for US allies that President Trump's foreign policy shifted from 'America First' to 'Peace through Strength' rhetoric-from an isolationist to a more Reaganite position.

There is still unease among the Japanese public about Trump's policy towards Japan. Trump might blow up the trade issue, a development that might unbalance both countries' national security interests.

While most US allies welcome the shift from 'America First' to a more conventional, internationalist foreign policy, Trump's unpredictable decision-making and the lack of clearly defined policy goals, principles and

values remain sources of deep anxiety.

Some Japanese welcome the withdrawal of US troops from Japan, while others even take this as a justification for developing nuclear weapons. However, at the moment these are distinctly minority views; they will not-and should not-be embraced by the government or the broader public.

The point of departure in considering Japan's security policy for the immediate future will be to assess the degree of threat posed to Japan, and determine whether Japan can and should deal with this alone, or modify its alliance policy. The country undoubtedly faces threats, and there are arguably issues that Japan needs to tackle on its own, such as boosting defence spending. Maintaining and strengthening Japan's alliance with America in addition to that would bolster Japan's security further.

It would be smart for Japan to try to do a lot more for its own selfdefence-including spending more. Japan currently spends less than 1 per cent of its GDP on defence, whereas Germany and even New Zealand each spend 1.2 per cent.

In January 2017 the Institute for International Policy Studies, a think tank established by former prime minister Yasuhiro Nakasone, issued a set of policy recommendations to the

EASTASIAFORUM

IN OUR NEXT ISSUE ... China's
influence
Japanese government in preparation for its dealings with the Trump administration. One was that Japan spend at least 1.2 per cent of GDP on defence. Likewise, a Special Task Force at the Mt Fuji Dialogue-a forum to discuss the current and future US-Japan relationship-called for defence spending to be increased up to the NATO standard of 2 per cent of GDP.

On 30 March 2017 the Research Commission on Security of the Liberal Democratic Party submitted a proposal to Prime Minister Abe for Japan to acquire the ability to launch counter-strikes at enemy bases in self-defence. The proposal was drafted as part of a larger effort to boost the nation's missile defences.

While it is true that there are enormous political barriers for these proposals to be realised, there is certainly financial and political potential for Japan to be more active. In a sense, Japan is a country of underused resources. Its consumption tax rate, at 8 per cent, is lower than most European countries. Its national security policy-from its interpretation of the right to collective self-defence to serious restrictions on arms sales-has been overly selfrestraining.

Political hurdles may seem to be prohibitively high, but if there is a strong cabinet with a clear foreign policy vision, underpinned by a strong electoral basis, as the Abe administration was in 2012-16, Japan can better prepare for the future in this increasingly unpredictable security environment. EMFQ

Fumiaki Kubo is the A. Barton Hepburn Professor of American Government and History at the Graduate Schools for Law and Politics, University of Tokyo. 


\section{Trump threat drives Japan and China closer}

YOICHI FUNABASHI AND HARRY DEMPSEY

S INO-Japanese relations have been stuck in a political quagmire for over six years. Tensions have resurfaced time and time again over the Senkaku/Diaoyu islands since September 2010, when a Chinese fishing boat rammed two Japanese coast guard boats and its captain was arrested by the Japanese. Japan harbours suspicions that Chinese aggression is aimed at an eventual retreat of the United States from Asia and the Pacific. And China continues to lambast Japan for its failure to face up to its history in the Sino-Japanese wars, as well as its contemporary push towards remilitarisation.

But speculation over a potential rapprochement between the two nations has emerged after Japanese Prime Minster Shinzo Abe's unexpected declaration that, 'Japan is ready to extend cooperation (with the Belt and Road Initiative [BRI]), in a speech on 5 June 2017. The statement was preceded by Toshihiro Nikai, secretary-general of the Liberal Democratic Party, representing the Japanese government at the Belt and Road Forum and a visit by China's top foreign affairs official, Yang Jiechi, to Japan. Tokyo has sounded out the possibility of a trilateral summit including South Korea in July 2017 (although that plan has now been postponed by Beijing) and reciprocal state visits by Abe and Chinese
President Xi Jinping, provisionally set for late 2018.

Abe previously tried to reset JapanChina relations in 2006 during his first term as prime minister, after their deterioration under his predecessor, Junichiro Koizumi. Narratives of Abe as a staunch nationalist ought to be shelved.

But what has motivated Abe to extend an olive branch again now?

US President Donald Trump has been a factor in two ways. First, US-China relations have struck upon a kind of high risk, fragile reframing, mainly because Trump is prioritising a solution to the problem of North Korea through Beijing. Abe has joined US calls for China to increase pressure on North Korea. Undoubtedly ensuring peace on the Korean peninsula would help drive the stabilisation of Sino-Japanese relations. In the long term, the most promising path to a solution of the North Korea issue-coordinated pressure facilitated by five-party talks-demands the improvement in

\section{Meaningful reconciliation}

is a long-term process of strategic alignment and

\section{compromise}

relations between Tokyo and Beijing, in addition to relations between other key players.

Second, uncertainty over the regional role of the United States under Trump makes it imperative to be active in improving relations. In the absence of a comprehensive regional strategy, Washington's commitments to Asian security are in doubt. Regional economic integration has been put at risk by the Trump administration's protectionist policies and rhetoric and its withdrawal of the United States from the TransPacific Partnership (TPP). Trump's transactional foreign policy make the United States' playing China off against Japan a real possibility.

Although Tokyo, which is pushing forward with the TPP without the United States (TPP-11), is hoping that the United States will come back at some point to this multilateral deal, there is a growing, sobering scepticism in policy circles that this is unlikely any time soon. Tokyo has begun serious contemplation of a clean-slate foreign policy absent US primacy. In the case of a recalibration like this, no relationship would be more important to stabilise than that with China.

To promote trade liberalisation and open regionalism, feasible options for Japan are the Regional Comprehensive Economic Partnership (RCEP), which already includes China as a member, and TPP-11, which should allow for Chinese participation on the condition it lives up to its high standards. Other 


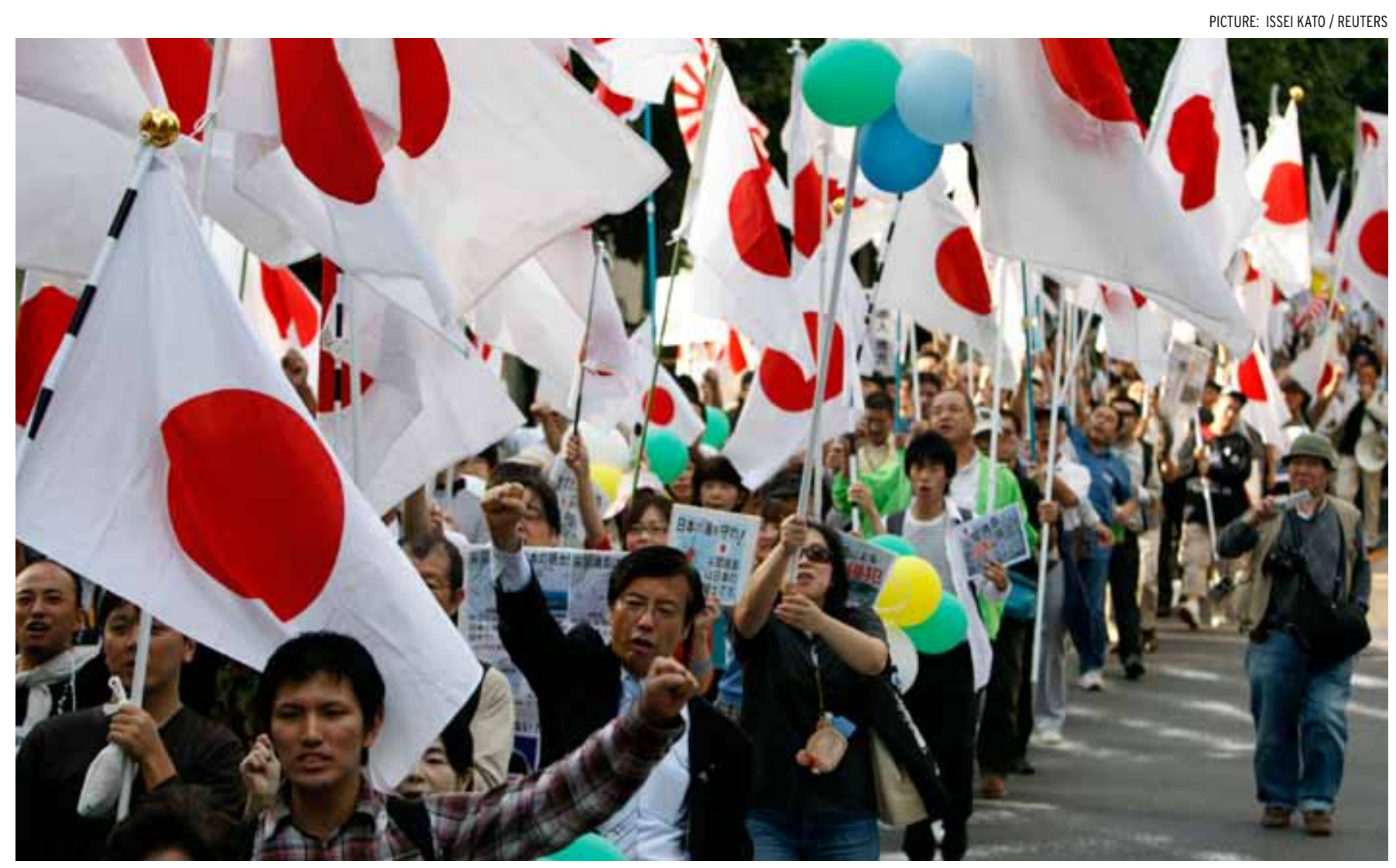

Demonstrators holding Japanese flags aloft march through Tokyo's Shibuya district in 2010, at the height of tensions over the Senkaku/Diaoyu islands. The issue is unresolved, but the two nations may be moving towards 'a mutually beneficial relationship based on common economic and strategic interests'.

member countries, such as Singapore and Malaysia, will only proceed with TPP-11 if it does not affront China.

BRI is another area for Abe to seek to stimulate the Japanese economy and gain diplomatic capital with Beijing. Consequently, Tokyo's overturning of its reservations about participating in the BRI have been in the spotlight. There is a line of thought that only involvement can lead to influence over the standards of BRI projects, as well as win-win benefits for Japanese companies.

But Abe's proposal to cooperate with the BRI came with strict caveats: it is critical for infrastructure to be open to use by all ... [and] for projects to be economically viable and to be financed by debt that can be repaid'. Direct engagement with BRI was prefaced by emphasising rules regarding state-owned enterprises agreed to by Vietnam in the TPP and book-ended by positing the benefits of Japan's high quality infrastructure partnerships. Abe's offer was tentative, informal and critical.

Three big challenges lie ahead. The first is whether Abe's assent to Beijing's strategic geo-economic program to win geopolitical cooperation is sustainable. Criticism stemming from values-based diplomacy could halt the warming of relations. The second is a US-China 'deal' over North Korea. On one hand, a breakdown would raise the possibility of military conflict that would hugely complicate China and Japan relations. On the other hand, success would likely see Japanese and South Korean concerns bypassed. The third is mutual and overwhelmingly negative public perceptions. In BBC opinion polls, only 3 per cent of Japanese citizens and 5 per cent of Chinese citizens view each other positively. Meaningful reconciliation is a long-term process of strategic alignment and compromise, not just sudden realpolitik play without grassroots groundwork.

Despite Abe and Xi lacking natural personal chemistry, they are strong leaders who give priority to their domestic economies. This adds plausibility to the prospect of their seeking a mutually beneficial relationship based on common economic and strategic interests. EAFO

\section{Yoichi Funabashi is the Chairman} of the Asia Pacific Initiative (AP Initiative), a Tokyo-based think tank. Harry Dempsey is a research assistant at AP Initiative. 


\section{Economy pushes Abe towards his endgame}

YUKINOBU KITAMURA

D RIME Minister Shinzo Abe

reshuffled his cabinet on 3

August 2017 in reaction to a series of political scandals and tumbling opinion polls. While he may have wished to boost his support in the polls, this is unlikely to happen. Instead, it looks as if the prime minister is fighting his political endgame.

There are four reasons for this.

History is against Abe. Japan's current business cycle began in November 2012, coinciding with Abe's appointment as prime minister on 26 December that year. But although the economy is reasonably robust for now, after 45 months, the current cycle could end at any time (Japanese business cycles since World War II have typically lasted between 40 and 60 months). This is bad news for Abe-no prime ministers except Shigeru Yoshida and Eisaku Sato have survived in office for more than one business cycle.

According to the Bank of Japan's Outlook for Economic Activity and Prices in July 2017, the Japanese economy will continue growing in 2017-18. After this growth is expected to drop in 2019 due to anticipated decline in infrastructure investment for the 2020 Tokyo Olympics. History shows that the pattern of business cycles continues regardless of government attempts to smooth out fluctuations through a mix of monetary and fiscal policy.
Second, Japan is facing pressure to drop its monetary easing policies. The monetary policy stances of the US Federal Reserve, the Bank of England and the European Central Bank indicate a move away from excessive monetary easing, but under the leadership of Governor Haruhiko Kuroda, it seems likely that the Bank of Japan will continue to implement quantitative and qualitative monetary easing (QQE) until the 2 per cent inflation target is achieved.

The first of Abenomics' 'three arrows, $\mathrm{QQE}$, is the only unique economic policy-the other two arrows, fiscal policy and growth strategy, are fairly orthodox. If the other major economies start implementing normal monetary policies, it will be difficult for the Bank of Japan to maintain its QQE policy. Financial institutions and other investors will inevitably shift their portfolios towards foreign assets with higher interest rates. The Ministry of Finance will face increased demand from domestic and international investors for an interest rate hike for Japanese government bonds. Sooner or later the time for cheap finance for government expenditure will be over. That will mean the end of Abenomics.

Third, except for the reaction of financial and currency markets immediately before and after Abe took office, economic indicators have been weak under his administration. Abe often cites the steady rise in the job openings-to-applicants ratio from 0.4 in 2009 to above 1.49 in May 2017, pointing out that this is the highest point reached after the historical record of 1.53 in February 1974, above the peak figure of the bubble period of 1.46 in July 1990.

But this ignores the very different labour market conditions Japan faces in 2017 compared with 1974 and the bubble period of the late 1980s. Current job openings are mostly for part-time workers or non-permanent workers, whereas job openings in the 1970s and 1980s were for full-time work for new job market entrants.

A NOTHER puzzling statement from the prime minister was that weak consumption demand was due to the 3 per cent consumption tax hike in April 2014, the first stage of a two-stage increase in the tax rate from 5 per cent to 10 per cent. In response, Abe postponed until October 2019 the second stage of the consumption tax hike (from 8 per cent to 10 per cent) that was initially scheduled for October 2015.

But his interpretation of weak consumption demand was wrong. The consumption slump was a result of 'rush' shopping for durables such as cars, housing and expensive electronic goods before the scheduled tax hike. In contrast, normal nondurable consumption has remained more or less constant over time, despite the April 2014 tax hike.

Increased consumption tax revenue was designed to finance expanding social security expenditure, including pensions, medical care, and aged care. 


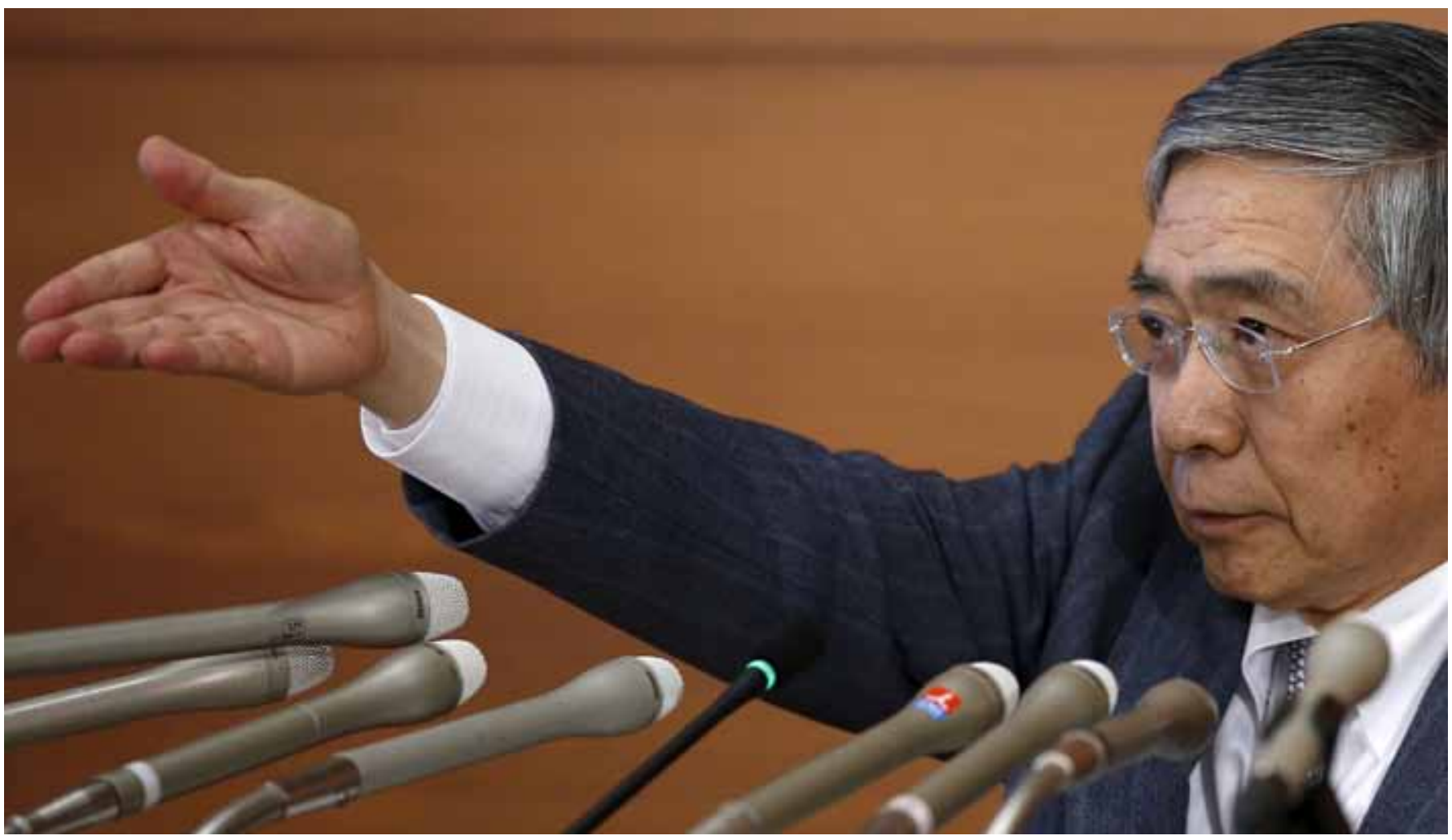

Bank of Japan Governor Haruhiko Kuroda at a news conference at the bank's headquarters in Tokyo. It will be difficult for Japan to maintain its quantitative and qualitative monetary easing policy if other major economies move to normal monetary policies.

Abe did not explain how he would manage the social security program without additional revenue from the consumption tax rise. This ambiguity about financing the social security program created uncertainty over the future course of pension benefits. This is the main reason for sluggish consumption among the elderly.

Lastly, Abe has lost significant popular support. Since last year, the Japanese media has reported on a series of scandals involving Abe and his wife's favours for friends and political supporters. The response of Abe and his aides to these controversies in Diet sessions has left voters unimpressed with the administration's apparent arrogance and insincerity. The fall in his public support below 30 per cent prompted the prime minister to reshuffle his cabinet to prevent a further slide in the opinion polls. But the reshuffle may not prove effective this time, since the drop is not a reaction to the mismanagement of any specific policy, but a response to Abe's personal attitudes.

A $\mathrm{BE}$ has also taken actions that have gone against the weight of Japanese popular opinion. For example, at a time when Western countries were imposing international sanctions against Russia over Moscow's military intervention in Ukraine, Abe approached Russian President Vladimir Putin to discuss the resolution of the Northern Territories issue. Likewise, on 3 May 2017 Abe again courted controversy and raised the spectre of a possible violation of the constitutional amendment process by abruptly announcing his plans to revise the constitution without consent of members of his ruling Liberal Democratic Party and its coalition partner, Komeito.

In a similar vein, despite 122 countries voting in favour of the Treaty on the Prohibition of Nuclear Weapons on 7 July 2017, and despite being the only nation to have suffered atomic bombing, Japan was one of 69 countries that did not vote to pass the accord. Most Japanese had hoped Japan would take the leading role in supporting the treaty. Prime Minister Abe did not agree.

With falling popularity and the sluggish economic recovery, Prime Minister Abe will have a hard time prevailing in the endgame. EAFQ

Yukinobu Kitamura is Professor at the Institute of Economic Research, Hitotsubashi University, Tokyo. 


\section{Empowerment: personal gain, corporate rewards}

KIMIE IWATA

W OMEN'S empowerment has been under discussion in Japan for more than 40 years.

In the 1970s and '80s, women's empowerment was largely discussed from a human rights perspective. This culminated in the enactment of the Equal Employment Opportunity Act in 1985 .

The focus shifted in the 1990s and 2000s towards responding to Japan's declining birth rate and shrinking labour force. Reflecting this shift, the Childcare Leave Act was enacted in 1990 and the Act for Measures to Support the Development of the Next Generation in 2003.

More recently, women's empowerment was identified as part of Japan's economic growth strategy by Prime Minister Shinzo Abe's administration. One manifestation of this is the Act on Promotion of Women's Participation and Advancement in the Workplace, enacted in 2015.

Today many business leadersparticularly those at large companies in metropolitan areas-recognise this issue as a critical challenge to corporate growth and have taken the initiative in responding to it. Japan has not seen such action on this scale before.

At a 2013 meeting with the heads of Japan's major business associations, Prime Minister Abe tabled a request for business to adopt a system allowing female employees to take three-year childcare leave. At a similar meeting

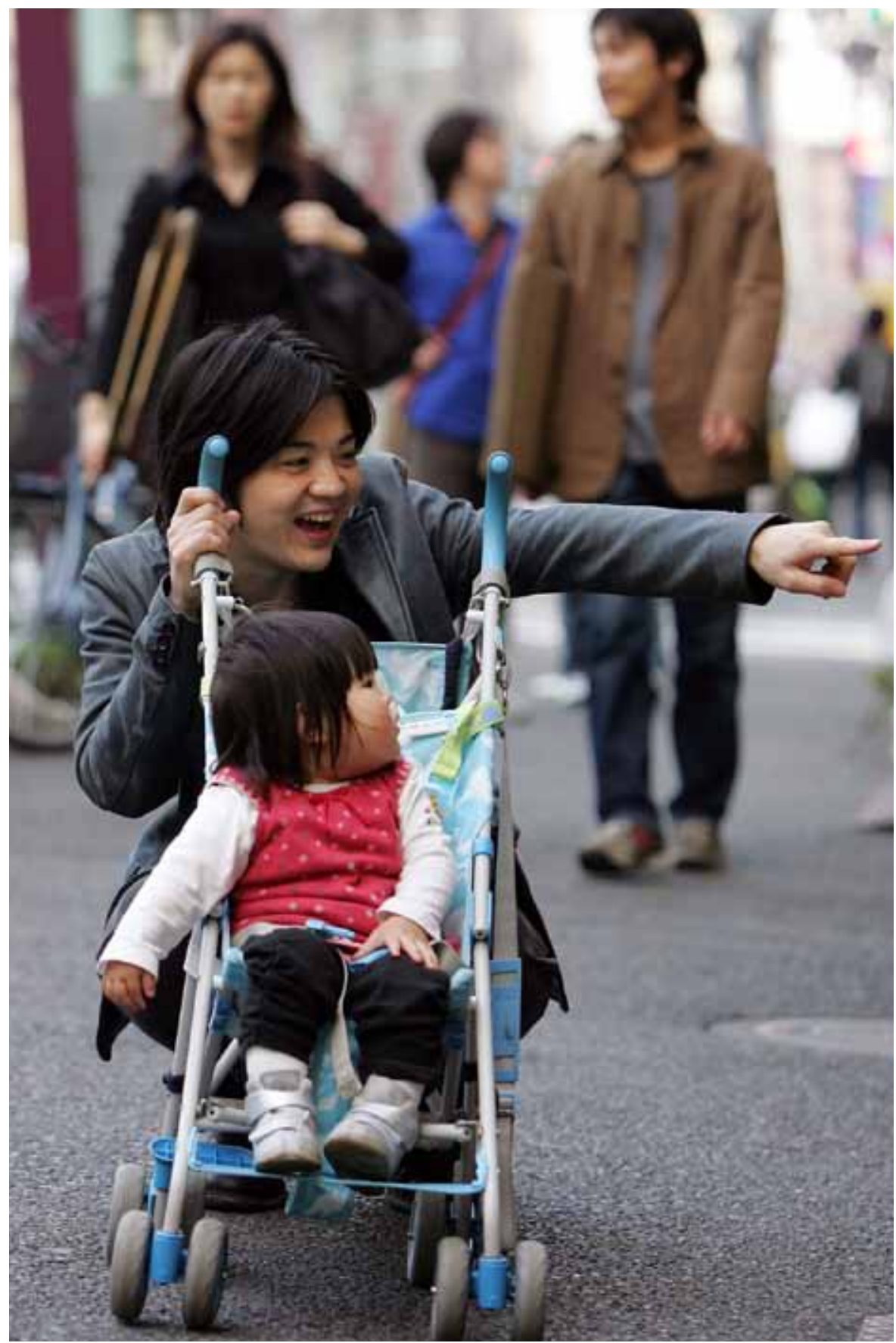

Not long ago it was unusual for fathers like Hiroki Minagawa-here seen taking his daughter Karin for an outing in Tokyo-to devote time to childcare. Now more Japanese men are getting involved in a nation where childcare is still largely seen as women's work. 
a year later, Abe asked business leaders to appoint at least one female executive officer at each company as quickly as possible.

As Abe's requests demonstrate, there are two requirements to be met to achieve women's empowerment in Japan: the continuation of women's careers during the childcare period, and women's career development and promotion.

The latest data show that 53 per cent of women continue to work after childbirth. This is the first time that this figure has exceeded 50 per cent and indicates an increase in the number of working mothers.

But the figures for women's career development and promotion are less positive. Only 13 per cent of management positions are held by women and just 3 per cent of Japan's executive officers are women. Given Japanese companies' long-standing practice of taking a long time to develop their employees, it will take some time for their efforts to train and promote female employees to bear fruit.

What are the big issues for Japanese companies to address? The first is to change their approach towards supporting work-life balance. Companies have tended to focus on supporting childcare by allowing women to suspend their work through systems such as childcare leave and shorter working hours. Companies competed in extending the length of these support periods.

But many companies have come to realise that while this approach might allow women to continue their career, it also impedes their career development and promotion. Employees develop capabilities by experience in the workplace. If the corporate support that women receive focuses on exempting them from work for a long period, it makes it difficult for them to develop capabilities, and so stunts their career development.

Accordingly, it is crucial to minimise work-exemption support and instead allow women to return to their full-time jobs as early as possible. To ensure that women can work full-time while taking care of their children, it is essential that organisations eradicate the practice of long working hours and embrace flexible work styles through initiatives such as flex-time and the right to work from home.

Further, companies should shift their focus in the measures used to support employees' work-life balance from women to men. At present, while 82 per cent of working women take childcare leave, only 3 per cent of working men take childcare leave. It will remain difficult to achieve women's empowerment while men are not ready to accept greater responsibility for childcare and household work. Yet it is an encouraging sign that among men-

To ensure that women

\section{can work full-time while}

taking care of their

children, it is essential

that organisations

eradicate the practice of

long working hours and

embrace flexible work

styles particularly younger men-this mindset has started to change, despite the deeply entrenched gender roles in Japanese society.

The second issue to be addressed is changing the traditional work style. For some time, long working hours and uniform, inflexible work-time management have been common in many Japanese companies. These practices likely derived from the view that long hours greatly contributed to the success of manufacturers during Japan's high economic growth period.

Men with full-time housewives have been able to take advantage of this work style, but it is not one suited to working couples, particularly where working mothers are concerned. Work style reform is essential both to secure the continuation of women's careers during the childcare period and to improve their chances of career development and promotion.

The growing prevalence of 'non-regular' workers has also had implications for women's work opportunities. There are two types of worker in Japanese companies. One comprises 'regular' workers, employed for an indefinite term. Normally they are employed in a wide range of jobs and often move to workplaces in different locations. They also work long hours.

The other type is made up of nonregular workers, who are employed for a fixed term. They include parttime workers, contract workers, and dispatched workers, who are employed by an agency and are sent to a company to work under the direction of that company. Non-regular workers perform a limited variety of jobs, usually remain at the same location and don't work long hours. As a result, career development opportunities are limited and they are paid much less than regular workers. 
To reduce personnel costs, Japanese companies in recent years have employed a higher proportion of non-regular workers. More than half of working women are non-regular workers. Given the present situation, it will be difficult to achieve women's empowerment without improving the working conditions of non-regular workers.

Finally, positive action is needed to support women's empowerment. Prohibiting gender discrimination and ensuring equal opportunities are basic requirements, but that will not be enough to eliminate gender inequality. Companies need to take various positive steps to narrow inequality more quickly.

The Act on Promotion of Women's Participation and Advancement in the Workplace requires companies to set numerical targets and formulate action plans, which are reported to the government and disclosed publicly. While these requirements are very soft, companies are taking the required actions, as they are monitored by job applicants and the public through information disclosure.

Why does women's empowerment deserve to be the core of Japan's growth strategy? Companies with a diverse workforce-and this is not just limited to women - are able to accurately identify needs of diverse consumers. Employee diversity also provides workplaces with diverse values, ways of thinking, interests and experience, which helps fuel innovation. When such views were expressed to business leaders 10 years ago, the reception was often dubious. Now they are on board. Japanese society is changing, slowly but steadily. EAFO

Kimie Iwata is President of the Japan Institute for Women's Empowerment and Diversity Management.

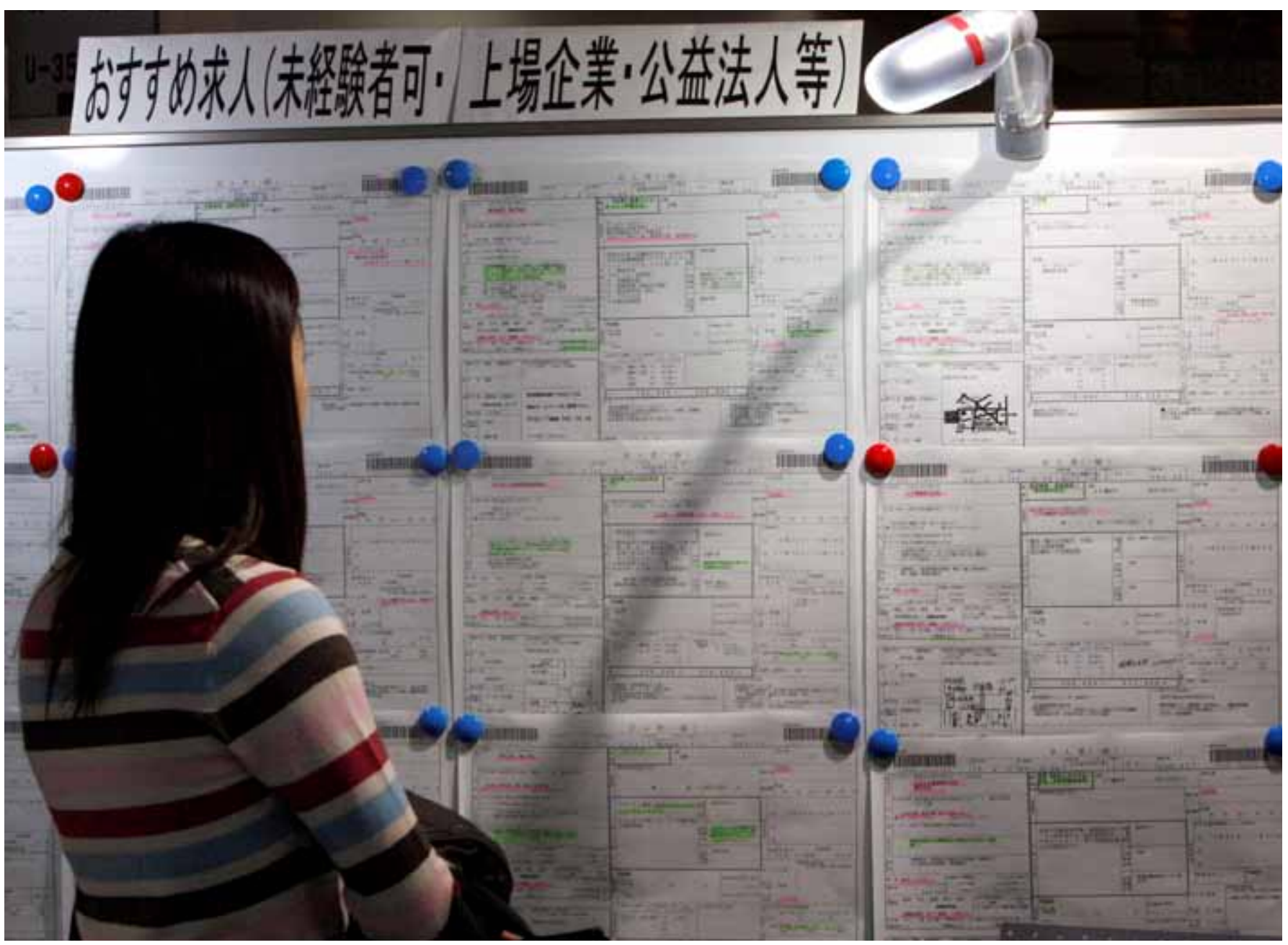

A woman looks at recruitment information posted on a board at a Tokyo employment centre. Many business leaders recognise that women's participation and advancement in Japan's workplaces is critical to corporate growth and have responded to the challenge on a scale not seen before.

PICTURE: YURIKO NAKAO / REUTERS 


\section{How is East Asia \\ [placed to avopid]

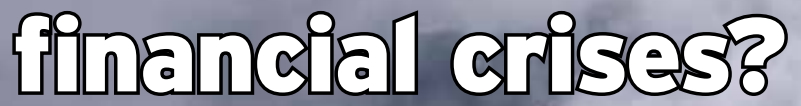

The Shanghai World Financial Center, right, and Jin Mao Tower reach skywards through cloud and rain. Are the financial foundations strong?

\section{BARRY STERLAND}

$\mathbf{T}$ WENTY years ago, on 2 July 1997, the Thai baht broke its peg with the US dollar, signaling the start of the Asian financial crisis (AFC). Coming around the time of the 10year anniversary of the global financial crisis (GFC), this is a good occasion to look at how well the region is set up both to avoid and to mitigate future crises.

The AFC had profound economic and political implications for the region and indeed the global economy. It has had equally profound impacts on the East Asian region's economic and geopolitical circumstances.

The sharp drop in the baht soon developed into full-blown crises in Thailand, Indonesia and eventually the much larger South Korean economy, as domestic financial institutions failed and foreign exchange sources dried up. Other regional countries, Malaysia and the Philippines among them, were also strongly affected. Growth plunged from positive 7 per cent in the years leading up to the crisis to negative 7 per cent, with Indonesian GDP declining 13 per cent. This brought about significant hardship and political instability. Financing packages of more than US $\$ 100$ billion were quickly organised to help countries to adjust to the sharp reversal of capital flows, including significant pledged resources from Japan, China, Australia and other ASEAN countries.

All these responses suggest that the region has a large stake in ensuring that crises are avoided, and that regional and global responses are effective.

So what have we learned two decades on? And what challenges remain?

The countries involved in the crisis have responded by improving their economic frameworks. Macroeconomic frameworks and domestic competitiveness have been greatly strengthened. The key reforms have been to introduce greater exchange rate flexibility and better financial supervision, while at the same time external settings - such as foreign exchange reserves and current accounts-have strengthened. As a result, the region has experienced solid growth in the intervening period and proved resilient in both the GFC and subsequent volatility. 
The region has also developed stronger collective institutions. The crisis gave impetus to efforts to become less reliant on the International Monetary Fund (IMF) due to profound mistakes made in its response to the crisis. There was an attempt, led by Japan, to set up an Asian Monetary Fund, which foundered on resistance from Washington and lack of consensus within the region.

The region nevertheless pressed ahead. The ASEAN+3 grouping, including China, Japan and South Korea, developed foreign currency pooling arrangements known as the Chiang Mai Initiative (CMI). This has been progressively strengthened. It now involves a US $\$ 240$ billion currency swap arrangement that has the capacity to assist members facing international liquidity issues or balance-of-payments crises. Thirty per cent of resources are 'de-linked' from IMF involvement, with the remaining resources contingent on an IMF program being in place. A new international organisation with surveillance and monitoring capabilities has also been created, the ASEAN+3 Macroeconomic Research Office.

Japan and China have separately offered bilateral currency swaps that could be used in a crisis. China has established bilateral currency swaps with 32 countries-including most of those in the region-which are primarily aimed at facilitating the internationalisation of the renminbi, but that have supported IMF programs both inside (Mongolia) and outside (Ukraine and Egypt) the region. Japan has recently pledged an additional US\$40 billion in currency swaps to ASEAN, explicitly to deal with balance-of-payments and liquidity events.
These arrangements have yet to be put to the test, but it would be a mistake to underestimate the extent of regional resolve to better manage future crises.

At the same time, the IMF has itself learnt many lessons from the Asian crisis. Financial crises are different from conventional macroeconomic crises brought about by lax macroeconomic policy. They require failing institutions to be rapidly cleaned up or capitalised, supported by macroeconomic policies to help in coping with the demand hit. This lesson was of course reinforced by the GFC a decade later. The IMF has also understood the need to ensure its programs focus on issues that are critical to recovery, rather than detailed lists of conditions. The latter can unnecessarily delay negotiations, risking greater disruption, and intrude into areas of national sovereignty, causing resentment and political risk.

$\mathbf{T}$ HE IMF has also strengthened its firepower and governance, and improved its advice. Fund lending capacity has been increased to around US $\$ 1$ trillion. The voting share of the dynamic emerging economies of Asia has been increased to better (though still inadequately) reflect their weight in the world economy. Fund policy advice has become more nuanced and suited to East Asian circumstances, and seems to be getting greater traction.

So the region is far better set up for crisis prevention and management. But 20 years on, challenges remain in the region to ensure that these arrangements are fine-tuned for today's risks.

Growth in the region continues to be strong and there is every reason to think this will continue in the near term. Indeed, growth in China appears to have stabilised while Japan is showing welcome signs of pick-up.

However, there remain significant common risks to regional growth over the short and medium term. Chief among these is the high and growing corporate debt and credit in China. Given the size of the Chinese economy and its links to the region, this poses threats to regional growth. While capital controls have been tightened, there are also risks that capital outflow pressures could return, which would provide another channel affecting financial stability in the region.

Japan's macroeconomic policies remain fully extended, leaving little capacity to respond to new shocks, while geopolitical risks-including on the Korean peninsula-could have economic reverberations.

A strengthening US economy is obviously positive for the region. However, as monetary policy normalises, financial conditions could tighten as markets overreact, or in response to badly timed fiscal stimulus or protectionist policies. Risks also remain in the Eurozone, including from a disorderly Brexit, and several larger emerging economies outside the region.

In the background, rising volumes and volatility in capital flows are seen as a key risk to the region. And there are inherent risks associated with modern financial systems that make them prone to panics, particularly following extended periods of calm.

The key thing to note about the above risks is that, if they come to bear, they are likely to affect the whole region and not just individual economies. AFC-style scenarios are still possible, but other quite different scenarios should be front-of-mind for regional policymakers when thinking about risk management and mitigation in the next 20 years. 
The first requirement is that countries in the region need to make maximum use of economic and policy dialogues in international and regional institutions. This includes better use of the region's collective voice to manage common risks and pursue common interests.

We need to ensure policy cooperation is strong in international institutions such as the G20. The G20 has many important roles, but crisis prevention and management are at the centre of its raison d'etre. The G20 as a forum for finance cooperation was in large part motivated by the AFC and other emerging country crises of the late 1990s. Its elevation to a leaders' forum was brought about by the need to respond to the GFC. Some of the G20's greatest successes since the GFC have been in the area of risk reduction, for example in strengthening financial regulatory standards.

T HE G20 will be an important forum for managing emerging risks and organising policy responses to an incipient crisis in the region. Any risk to large Asian emerging economies will be a global risk, given the size and interconnectedness of the regional economy, its contribution to global growth, and significant spillovers to other economies outside the region. This means that any response will need to involve systemic economies outside the region, particularly the United States. Asia is well represented in the G20, with six members, and will need to use this forum assertively in such an eventuality to coordinate macroeconomic responses and marshal crisis resources.

The common risks facing the region mean that we need good ways to access financial resources from outside the region. While the economies in the region are more resilient, the size of emerging economies and gross capital flows are so large that any significant shocks will need a combination of internal and external resources.

This places a premium on continuing to repair and strengthen the region's relationship with the IMF so that it is an early rather than a last resort. The IMF needs to continue to improve its role as a trusted partner. Recent test runs with the CMI and newly agreed approaches to cooperation with regional arrangements will help in this ongoing task. The region also needs to highlight to its own citizens some of the improvements that have taken place in the past two decades. The location of next year's IMF-World Bank annual meetings in Bali, the first in emerging Asia since the crisis, is an opportunity to further these twin tasks.

The priority for now is to make sure IMF programs are accessed when needed. Precautionary IMF arrangements, which provide for the Fund to be involved ahead of a crisis, can help in quickly catalysing other forms of assistance. The region should consider making use of existing credit line arrangements and new policy coordination instruments, and support development of new liquidity instruments for well-performing economies. This will become more pressing if risks become more prominent.

And the region should work together to ensure the IMF balance sheet remains strong. Borrowing arrangements provide around half of its lending capacity and will expire around 2020. Proposals to lift the permanent quota (or equity) of the Fund will face political challenges, including within the United States and from other major shareholders in Europe.
The region has a considerable stake and influence in this debate, and will need to make the case that the United States and other major shareholders have multiple interests in maintaining this important global public good.

The potential scale of possible crisis responses and the need for rapid action means that regional resources need to be able to work smoothly in a crisis and link with other sources outside the region.

The CMI needs to be further strengthened to ensure it is fully operational in a crisis, including with the IMF. Priorities are to ensure that gaps identified in recent test runs with the IMF are addressed (in both institutions) and that there is greater transparency on the procedures and criteria for triggering support. This will build market credibility.

D Otential regional contributors, including those outside existing CMI arrangements, such as Australia, should collaborate to ensure bilateral resources link well with existing global and regional mechanisms.

The countries of the region are right to stay focused on reducing risk through prudent domestic policy settings, and this is the surest way to avoid a repeat of the events of 20 years ago. However, the region should be doing more given the changed circumstances of growing common systemic risks. This involves working together in international institutions to manage risks. It also means ensuring the region's own defences are deepened and widened, while ensuring global risk-sharing mechanisms like the IMF remain strong and accessible. EAFO

Barry Sterland is a Visiting Fellow at the Brookings Institution. 
PICTURE: DANNISH SIDDIQUI / REUTERS

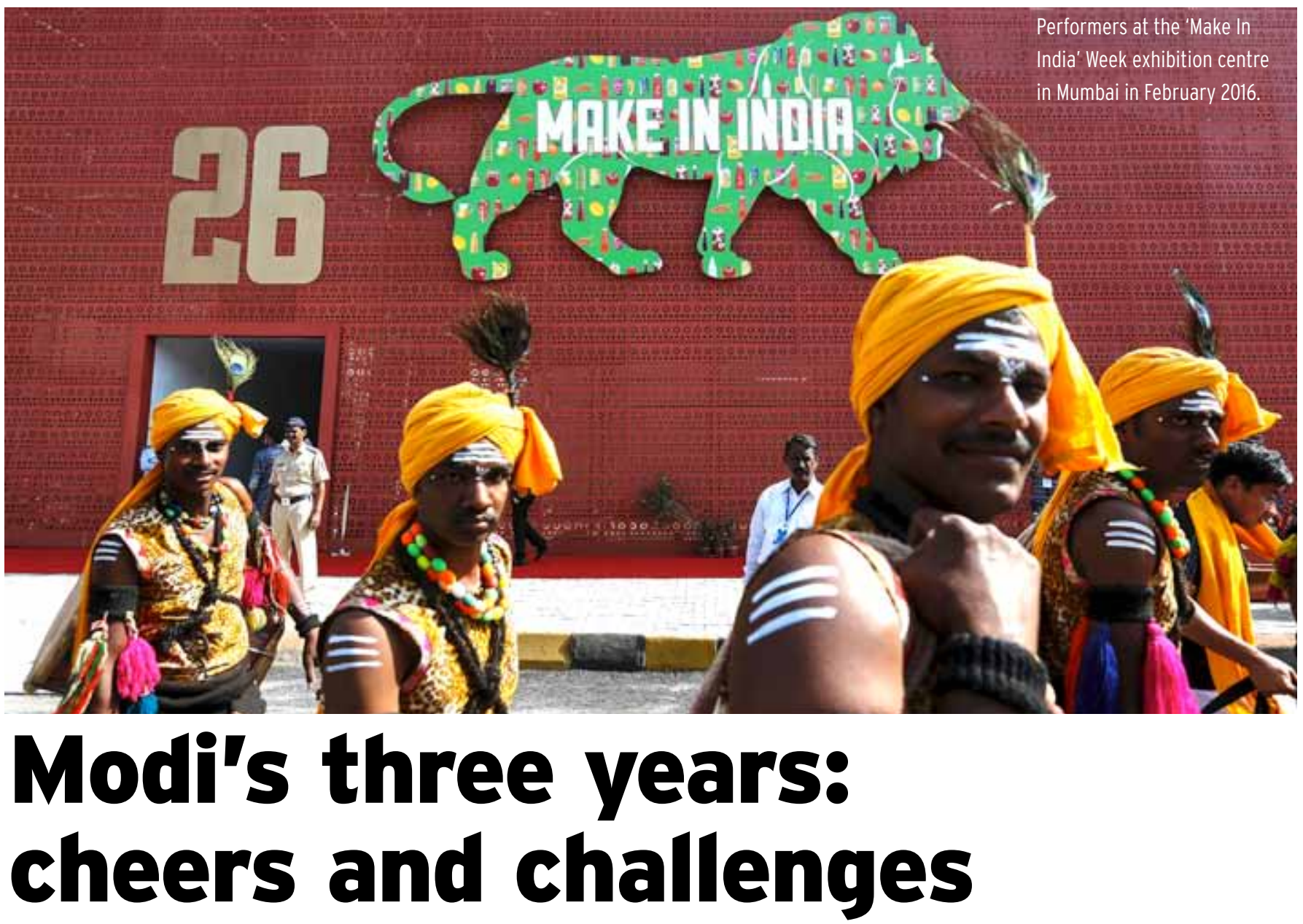

AMITENDU PALIT

T HAS been more than three years

since Narendra Modi, India's 15th prime minister, guided the Bharatiya Janata Party (BJP)-led National Democratic Alliance to a spectacular victory in the parliamentary elections in May 2014. Modi's tenure has been under the spotlight, largely due to his contrasting successes and failures.

Modi has been remarkably decisive and active in several areas of foreign and domestic economic policy, but on some major economic fronts his achievements have been disappointing. His tenure has also witnessed the widening of certain social divisions in India.

Modi came to office enjoying the image of a strong and capable economic administrator. This image was fostered by success in making India's western coastal state of Gujarat-where he served as chief minister for more than a decadean attractive and business-friendly location for foreign investors. It was only natural that his election as prime minister would generate enthusiasm among both foreign and domestic investors.

Modi was widely expected to push ahead with economic reforms and clean up the messy regulations that make India a difficult place for doing business. His signature 'Make in India' initiative, launched within a few months of his assuming office and aimed at making India a global industrial powerhouse, resonated well with these early impressions. So did his repeated calls to improve the ease of doing business in the country.

Modi's government has significantly liberalised foreign investment rules in 'sensitive' sectors that were previously either blocked to foreign investment, or only allowed it to a small degree and under tight conditions. The defence manufacturing, food processing, mining, railways, retail and civil aviation sectors were among those opened up.

These enabling policies and Modi's personal image have been major drivers of a surge in investor interest in India, as Modi continues to pitch India to foreign investors as a country with 'one of the most liberal 
FDI regimes. With a current GDP growth rate of more than 7 per cent and signs of improvement in ease of doing business, India attracted around US $\$ 60$ billion in foreign direct investment (FDI) in 2016-17, making it one of the world's largest recipients of foreign investment.

Euphoria over enhanced investor interest and high FDI inflows have been accompanied by disappointment over unfinished reforms. Modi's political capital and significant electoral mandate had created expectations that his government would be able to implement reforms that would remove rigidities in land and labour regulations, but steps to fulfil these expectations have yet to materialise.

Efforts to amend the land acquisition regulation enacted by the Manmohan Singh administration that heavily increased the cost of acquiring land for infrastructure projects have not succeeded. Regulatory reform aimed at removing inflexibilities from the labour market has also remained unaddressed.

Both reforms are necessary to improve the investment climate and ease of doing business in the country. The fact that the Modi government has not been able to progress on these reforms-despite the large majority the National Democratic Alliance enjoys in the Lower House-points to persistent difficulties in building consensus on politically sensitive land and labour reforms.

The Indian economy today nurses serious vulnerabilities despite high rates of GDP growth. Of foremost concern is the lack of jobs for the country's large youth population. High growth is not producing adequate employment for India's growing workforce, and further jobs are being squeezed from the market by the advent of artificial intelligence and labour-saving technologies in industries like automobiles and IT. Prime Minister Modi's biggest economic challenge is to create enough jobs to ensure that India's demographic dividend does not turn out instead to be a liability.

The socioeconomic ramifications of fewer jobs are compounded by agrarian distress. The incidence of farmers committing suicide due to bankruptcy continues to increase, forcing large states like Uttar Pradesh, Maharashtra and Punjab to write off big chunks of agricultural loans. Such waivers would force national banks, already saddled with large volumes of non-performing loans, to further enhance risk perceptions of agricultural loans and lead to a squeeze on rural credit.

W HILE many farmers are forced into debt by crop failures precipitated by climate changeinduced weather aberrations, loan waivers are merely ad-hoc political responses to agrarian distress. The Modi government is yet to find a solution to the structural issue of sustaining farmer incomes and improving their ability to service loans. Inadequate jobs and a troubled agricultural sector could become serious political challenges for Prime Minister Modi, given that youth and farmers comprise sizeable portions of the electorate.

Two of the Modi government's most far-reaching economic initiatives have been the demonetisation of more than 80 per cent of currency in circulation in November 2016 and the introduction of the goods and services tax (GST) from July 2017. The demonetisation was implemented to flush out black money and make the economy less cash-reliant by encouraging digital transactions. The GST aimed to create a 'common' market for goods and services by rationalising a plethora of federal and provincial indirect taxes.

While it is not clear how much black money was unearthed by demonetisation, the sudden lack of access to cash hit the informal sector of the economy, forcing a contraction in economic activity. Though not having disruptive effects similar to demonetisation, the GST is far from ideal. Apart from having multiple rates, it leaves out significant commodities like crude oil, petroleum products, alcohol and electricity from its ambit.

Both demonetisation and GST highlight the Modi government's proclivity to 'shock' the economy into a formal, digital and structured shape, with little attention to the costs of such a transformation. The tendency is also noticed in the alacrity with which Aadhaar, the unique identity number for residents, is being made mandatory for all interactions between citizens and the state, including maintaining bank accounts, buying property, furnishing tax returns and registering deaths.

On economic management, Modi and his team deserve praise for maintaining policy continuity by taking forward important initiatives of the earlier government like the GST and Aadhaar. But by ignoring the costs of implementing these measures on an economy where the bulk of livelihoods are provided by the informal sector, the government's drive to formalise the economy risks leaving many Indians behind. Coming on the back of paucity in jobs and the inability to remove rigidities in land and labour markets to accelerate investment and enhance hiring, the long-term socio-political costs of administering economic 
shocks could be significant.

Vigilantism in India is also

on the rise, particularly where

the consumption of beef and the

protection of cows is concerned.

There are several instances of people

being lynched by irate mobs on

the suspicion of carrying beef and

slaughtering cattle. The courts have

withheld implementing government

orders aimed at banning the slaughter of cattle.

Though Prime Minister Modi

has condemned mob violence in

protecting cattle, vigilantism is being

seen as a manifestation of intolerance

in certain parts of the society towards

minorities who consume beef.

Concerns are mounting fast that these

actions reflect a rapidly polarising

country under a government

favourably inclined towards a right-

wing pro-Hindu agenda.

While such polarisation might eventually divide the electorate between BJP and non-BJP political allegiance-with the former hoping to lock down the support of the Hindu majority - the outcome has serious consequences for India's social harmony.

Where Prime Minister Modi has performed beyond expectations is in his conduct of foreign policy. Under Modi, India's external engagement has been infused with a new-found robustness. India appears to have firmly shed inhibitions of a 'nonaligned' past and has begun practising 'multi-alignment' with economic benefits becoming the major focus of foreign policy. India has begun building partnerships with countries like Israel and Iran, struck nuclear fuel deals with Australia, Canada and Japan, reached out to small island states in the Indian Ocean and South Pacific and brought new energy in working with neighbours.
India appears to have

firmly shed inhibitions of

a 'non-aligned' past and

has begun practising

'multi-alignment'

India's renewed enthusiasm for working with its neighbours has had mixed successes. While relations have improved remarkably with Bangladesh and Sri Lanka, and partly with Nepal, ties with Pakistan haven't mended. There have also been spats with China on the Belt and Road Initiative, which has sparked territorial concerns in India. But elsewhere, the Modi government has been remarkably pragmatic in collaborating with China, particularly in forums like the BRICS, the Shanghai Cooperation Organisation and the Asian Infrastructure and Investment Bank.

At the multilateral level, Modi has emerged as a champion of the global fight against climate change, most noticeably through global initiatives like the International Solar Power Alliance, which seeks to make solar energy the core source of electricity for countries. And despite an active stance in the fight against climate change, Modi has been able to maintain close ties with the Trump administration in the United States and has consolidated India's relations with its old ally, Japan.

Modi's robust and multialigned foreign policy has not been accompanied by a similarly energetic and active foreign trade policy. India's traditional image of being 'difficult and defensive' in trade negotiations continues. India has been unable to conclude various trade pacts it is engaged in, both in terms of bilateral deals with Canada, Australia and the EU, as well as regional deals such as the Regional Comprehensive Economic Partnership.

Indeed, trade has hardly featured as a priority for the Modi government. The establishment, while favouring foreign investments in the economy, appears allergic to imports, giving rise to impressions that the 'Make in India' initiative is actually a repackaging of an import-substitution strategy.

Looking ahead, the contrasting successes and failures in three years of Modi's prime ministership underscore the changes his style of leadership have brought on. India now has a different form of federal economic management, dictated by Modi's strong leadership style and eagerness to implement radical policies. But at the same time this strong style hasn't yet been able to bring together divergent groups on the land and labour reforms that require the involvement of multiple stakeholders, including state governments.

Modi has left his indelible imprint in areas where he has a 'free' hand, particularly in foreign policy and economic policies that are under his direct control and management. Elsewhere, in economic policies such as the GST, compromises are noticeable. It remains to be seen in the next couple of years whether Modi is able to address looming domestic economic challenges with as much skill and dexterity as he has shown in foreign policy and whether doing so would require discernible changes in his style of management. EAFQ
Amitendu Palit is Senior Research Fellow and Research Lead on trade and economic policy at the Institute of South Asian Studies, National University of Singapore. 


\section{The South China Sea seven years on}

\section{MICHAEL MCDEVITT}

\section{S}

EVEN years ago at the Hanoi

ASEAN Regional Forum, then secretary of state Hillary Clinton made a very public, and-for the Chinesesurprising, intervention into the South China Sea (SCS) disputes. This move implicated the United States in a way that was probably unforeseen in Washington and in the region at the time.

While the objective of the Clinton statement was to indicate that peace and stability in the SCS was a US interest, in hindsight, by choosing to be so publically involved-over time exhorting China to play by the rules, stop building and militarising islands, and abide by the Permanent Court of Arbitration findingsWashington found itself trying to shape Chinese SCS activity with absolutely no practical leverage (short of the use of force or imposition of trade or economic penalties, actions Washington correctly was unwilling to countenance).

Beijing ignored US exhortations and essentially told Washington to mind its own business. In Beijing's view, Washington was involving itself in a matter of Chinese sovereignty and security. Beijing is convinced that all the land features in the SCS and, at a minimum, the maritime entitlements appertaining to them, are Chinese territory.

Beijing has been waging a patient long-term campaign to regain these claimed maritime rights and interests. For six decades since the 1950s when Beijing occupied abandoned Nationalist Chinese islands in the eastern Paracels, China has inexorably

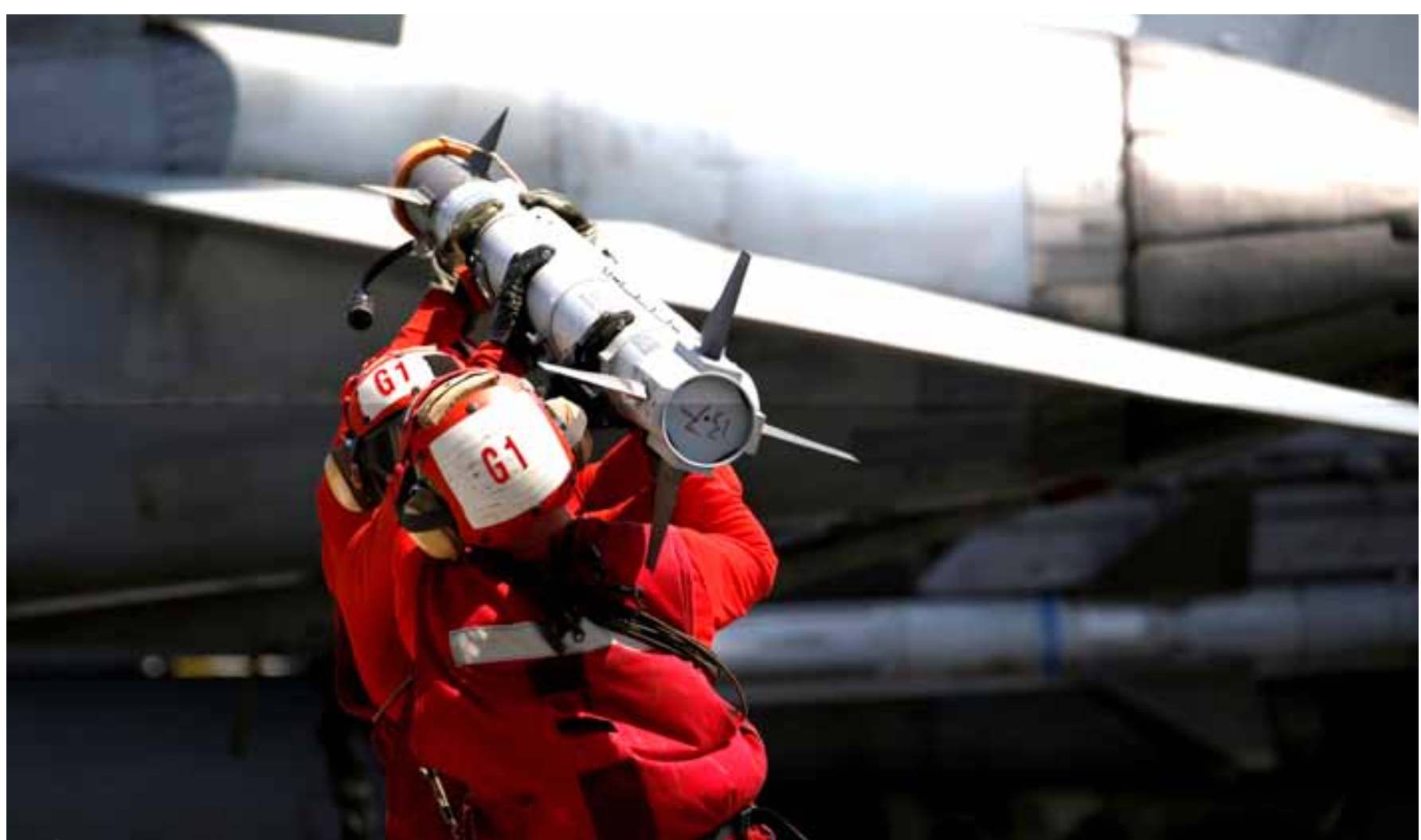

United States Navy personnel carry a missile to an F18 fighter on the deck of USS Carl Vinson during an exercise in the South China Sea in March 2017. US forces continue 'to sail, fly and operate where international law permits'.

PICTURE: ERIK DE CASTRO / REUTERS 
collected islands, rocks and other features in the SCS through the combined use of force, coercion and occupation. Turning its seven small and long-occupied toeholds in the Spratly Islands into major military facilities is just the latest manifestation of this long-term strategic objective.

Beyond recovering 'lost sovereign territory', the defence of China is also directly related to control of the land features in the SCS. Bases in the Paracels and Spratlys provide strategic depth for an enemy planning to attack China via the SCS. Hainan is especially important to the People's Liberation Army since Beijing has decided to homeport its growing ballistic missile submarine force at the southern end of that island.

China is also hugely dependent on the maritime trade routes that pass to the west of the Spratlys, including trade associated with the much-touted 21st Century Maritime Silk Road. Controlling these islands is the best way for China to make certain no one else does. Now, with three large, newly constructed airfields, it will be able to conduct routine airborne surveillance of its SCS maritime approaches, along with much of Southeast Asia.

So, seven years on, where are we today? What has US policy aimed at moderating China's SCS behaviour accomplished, and what is the way forward?

First, the United States played an indirect but important role in advocating Manila's decision to go to the Permanent Court of Arbitration over Chinese claims and actions in the SCS. Although Beijing has so far refused to honour the ruling, it provided clarity to a number of the ambiguities in the United Nations Convention on the Law of the Sea that pertain directly to the SCS, while driving a legal stake into the heart of
Beijing's historic rights claim. Beijing is now permanently burdened with an extremely adverse legal opinion.

Second, no vital US interest has been compromised. Shipping continues uninterrupted, while the United States ignores (daily, if you believe the Chinese complaints) its requirement for prior approval for military operations in China's exclusive economic zone. The US Navy and Air Force continues to sail, fly and operate where international law permits; an important signal of national policy intentions and military deterrence that more nations should adopt.

Third, the US Mutual Defense Treaty (MDT) with Manila remains in force and China has not attempted to test it by shedding Filipino blood. The Vietnamese are even more dug in on their 25-odd Spratly holdings and show no interest in decamping. Rather, Hanoi is adding extra military capabilities to make Beijing think twice before trying to force them out. In short, a more-or-less credible

\section{Despite having}

\section{permanently shifted the}

Spratly military balance

in its own favour, China

still faces the problem

\section{of how to get the other}

claimants off their

Spratly holdings without

starting a war deterrent is in place to thwart an attempt to push either the Vietnamese or the Filipinos off their Spratly holdings.

What's more, in the wake of the Permanent Court of Arbitration award, Beijing had to swallow its pride and embrace the blatantly opportunistic ploy that Philippine President Rodrigo Duterte pulled, which allowed Beijing to save face in return for Chinese loans. Duterte now has the big infrastructure loan promises he desired and still has the MDT in his back pocket. The fact that Duterte is hanging on to the MDT is the best example that a positive security relationship with Washington is still a valued commodity in Southeast Asia, as is the recent visit of the Vietnamese prime minister to Washington in May.

In sum, while Beijing's objective to gain control of all the Spratlys has not been forsworn, it has likely been delayed. Despite having permanently shifted the Spratly military balance in its own favour, China still faces the problem of how to get the other claimants off their Spratly holdings without starting a war.

US policy has caused an international spotlight to be pointed at the SCS, raising doubts and apprehensions around the globe regarding China's future behaviour. Given the very poor hand Washington had to play, this is likely the best possible outcome that could have been achieved peacefully. The Trump administration would be wise to continue to keep the SCS dispute in proper perspective to other more important interests and issues that Washington has with Beijing. EAFO

Michael McDevitt is Senior Fellow, Center for Strategic Studies, CNA, Arlington, Virginia. 


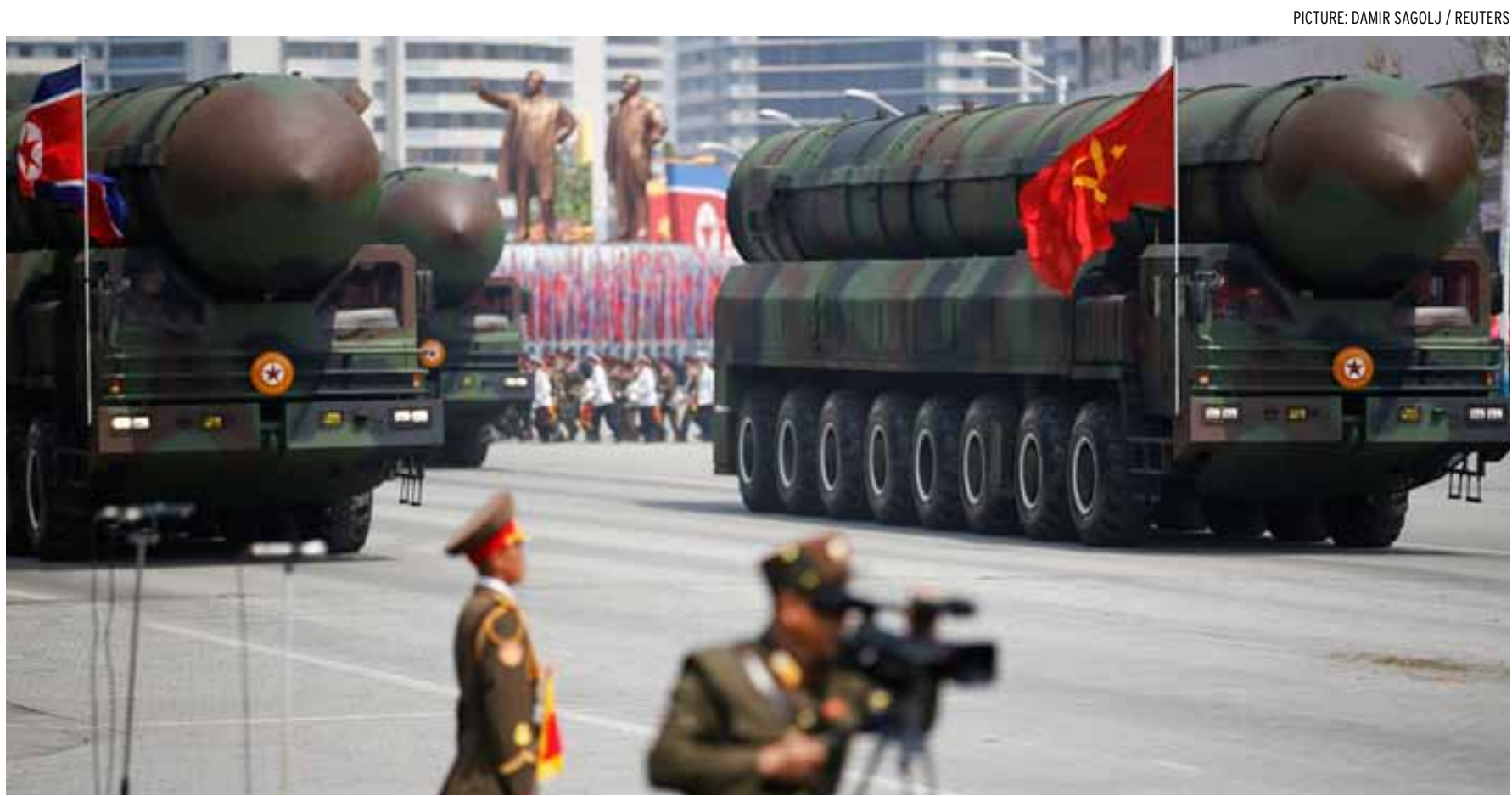

Intercontinental ballistic missles roll through Pyongyang at a parade in April 2017 marking the birthday of regime founder Kim II Sung.

\section{Shifting the momentum on the Korean peninsula}

\section{CHEN DONGXIAO}

D EIJING has long held three

D objectives for East Asia, and the Korean peninsula in particular.

The first is to promote general peace and stability premised on North Korea's diplomatic normalisation with the United States and South Korea.

The second is to realise the denuclearisation of the Korean peninsula by dissuading Pyongyang from continuing its nuclear weapons and nuclear-capable missile programs. For China, this is the key to avoiding the possible nuclearisation of the whole East Asian region.

Third, China aims to preserve a regional strategic equilibrium between itself and the United States by maintaining its own defensive edge and a reliable level of strategic deterrence.

But the current security situation on the Korean peninsula seems to be moving further away from Beijing's preferred objectives. Of most concern is the explosive and uncontrollable risks engendered by North Korea stepping up the development of its nuclear weapons and missile capabilities.

The prospect of rolling back the nuclearisation of Korean peninsula has progressively faded away. Pyongyang has increased both the scope and speed of its nuclear and missile capability development. Since Kim Jong-un inherited power six years ago, Pyongyang has already conducted three nuclear tests and a fourth test is said to be imminent. Pyongyang has also undertaken more than 75 shortto immediate-range ballistic missiles tests, including a submarine-launched test.

In July 2017 alone, Pyongyang conducted two long-range missile tests. Many believe that the missiles tested are intercontinental ballistic missiles (ICBMs) with a range capable of striking the United States' mainland-a significant and surprising advance. Despite differing assessments of the missiles' targeting systems and their ability to deliver a nuclear device or significant payload, Pyongyang's status as a de facto nuclear weapon country already seems beyond doubt. The real question now is how long 
Japan and South Korea will maintain their confidence in the US nuclear protection umbrella before they move to develop their own nuclear deterrence capabilities.

Meanwhile, the United States has increased its military assets and strategic presence in the region. Seeking to ratchet up military pressure on North Korea, the United States has conducted air operations over the Korean peninsula. It has also participated in military exercises with its allies, South Korea and Japan.

Despite Secretary of State Rex Tillerson's 'four nots' reassurance to North Korea-that the US will not seek regime change, the collapse of the regime, an accelerated reunification of the Korean peninsula or an excuse to send the US military north of the 38th parallel-many in the United States, including a significant number in Congress, believe that the time for negotiation with North Korea is over. President Trump has been called upon to follow through on his 'maximum pressure' policy, including pressing China to execute financial blocks and economic embargoes on North Korea.

Whenever hostility and tension between Pyongyang and Washington is on the rise, so is the risk of miscalculation between two sides and the possibility of inadvertent military confrontation. President Trump's petulant and unpredictable personal character should not be understated in such a highly tense atmosphere.

Regional security and strategic stability are at the risk of breaking down. The US deployment of the Terminal High Altitude Area Defense system (THAAD) in South Korea has not only undermined the strategic deterrence capabilities of both China and Russia, but also strained relations between Beijing and Seoul.

Perhaps more importantly, the brawl over North Korea's nuclear issue has made Beijing's relations with Washington more unpredictable. Washington complains that Beijing, with its unique economic sources of leverage, has fallen short of carrying out its obligations to rein in Pyongyang's misbehaviour. Beijing in return argues that Washington has long failed in its own attempts at riskreduction on the peninsula.

Pyongyang of course must be blamed for its violation of UN resolutions and is responsible for rising tension and instability across the region. But it is widely recognised that North Korea's nuclear issue is both the cause and result of the security situation on the Korean peninsula. The root cause of North Korea's decision to develop nuclear weapons is the long-term and deeply entrenched hostility and adversarial relations from Washington and Seoul towards Pyongyang.

Today the Korean peninsula is still framed by Cold War structures, and the 38th parallel remains home to the world's largest and most dangerous military standoff. From Pyongyang's perspective, developing nuclear

\section{Beijing's decision to turn}

\section{the screws on North}

Korea this year is the right

step forward to ensure

Pyongyang pays a higher

price for its irresponsible

behaviour weapons provides an element of deterrence against a regime-change attack from the United States and other outside threats by raising the cost of conflict.

Pyongyang will never shy away from pressing for more concessions by leveraging its nuclear weapons program, even at the expense of China's national security interests and overall regional stability. North Korea should also recognise that its persistence on nuclear weapons development has made the prospect of improving national economy-the so-called byungjin policy-a mission impossible.

To a large extent, the spiralling tensions over the North Korea nuclear issue should also be attributed to Washington's and Seoul's continuous flip-flopping on their policies towards Pyongyang, which has had damaging implications for their policy credibility. The deficit of strategic collaborations and lack of synchronised efforts among the key stakeholders, including China and the United States, have given Pyongyang more opportunities to drive wedges between these states.

These wedges have enabled North Korea to evade the pressure of international community and reduced the efficacy and credibility of both the carrots and sticks wielded before them. What's more, the deeply entrenched strategic suspicion among key players-particularly between Beijing and Washington-has rendered the supposed international united front against North Korea's nuclear program even more fragile and vulnerable.

For more than a decade, Beijing has tried very hard to influence the security trajectory of the Korean peninsula, convening the Six Party Talks, encouraging efforts of reconciliation between Washington and Pyongyang and urging the 


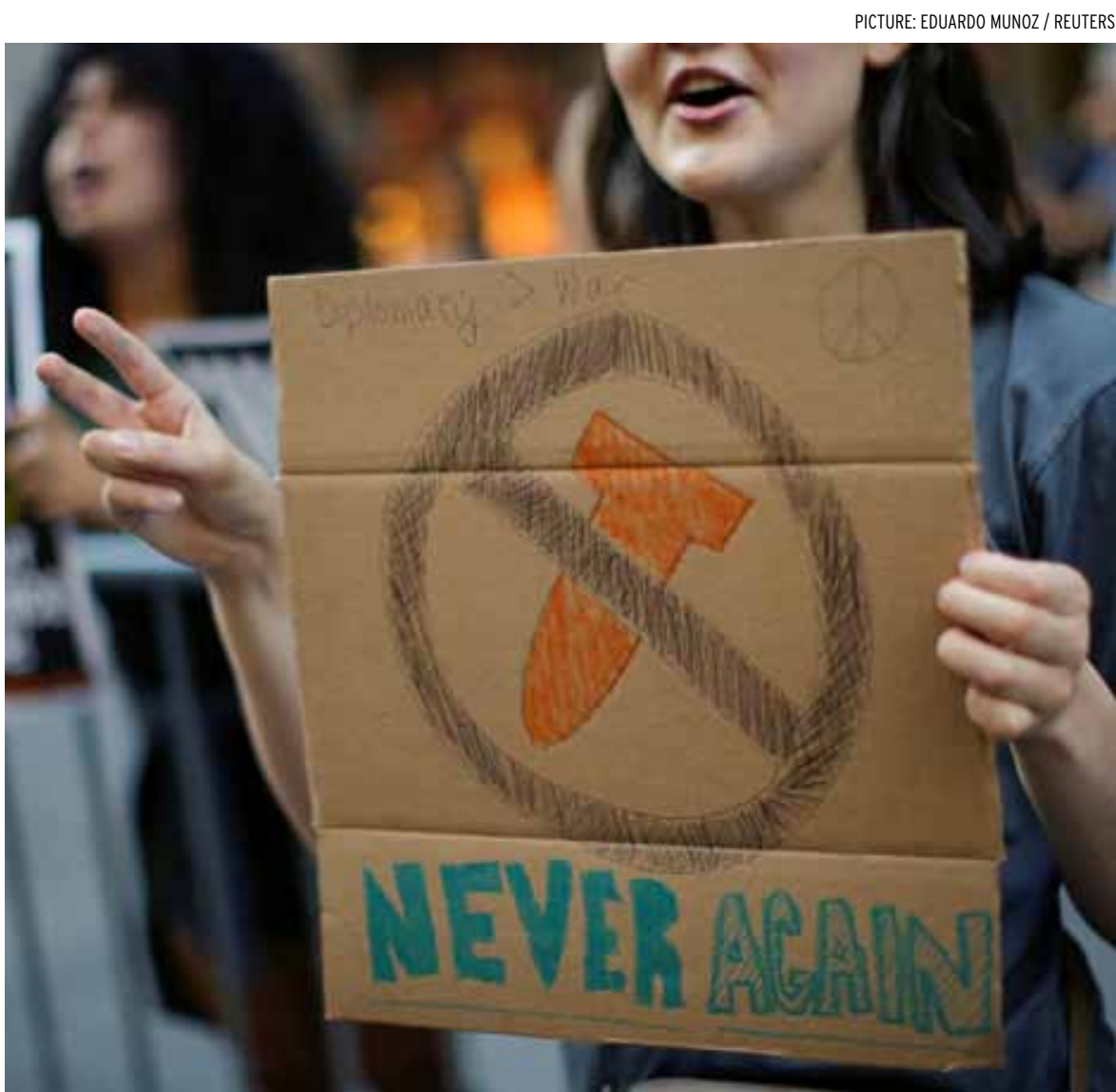

Demonstrators at a New York protest in August 2017 demand immediate talks with North Korea, but a significant number in the US Congress believe the time for negotiation has passed.

maximum restraint of all parties to avert escalating tensions, particularly between the North Korea and the United States.

But there is still room and a need for improvement in Beijing's policy, particularly on how to send a stronger and clearer message on opposition to Pyongyang's nuclear weapons and other related programs that violate UN resolutions. Beijing's decision to turn the screws on North Korea this year is the right step forward to ensure Pyongyang pays a higher price for its irresponsible behaviour.

Having said that, it is Pyongyang and Washington that hold the key to the final solution of the North Korean nuclear crisis. Beijing will definitely reject the rebuke from Washington and others that China has done little to help solve the crisis.

It is likely that Beijing will continue to pursue dual-track approaches, simultaneously seeking to roll back North Korean nuclearisation and encouraging constructive dialogue between Pyongyang and Washington.

On the one hand, Beijing is determined to send a stronger message to Pyongyang that its nuclear weapon development will face tougher and more resolute opposition from the international community, including China. Only by freezing and finally quitting its nuclear and related missile programs according to the UN resolutions will Pyongyang be able to get economic, diplomatic and security returns from the international community. While Beijing will spare no effort to maximise diplomatic opportunities for the management of the Korean nuclear crisis, it has been also stepping up its preparation for the worst-case scenario.

On the other hand, encouraging reconciliation between Washington and Pyongyang, as well as between Seoul and Pyongyang, is no less significant. The challenge is how to integrate this pressure and dialogue in a more synchronised approach so that dialogue with Pyongyang is as clear, strong and credible as possible. As a first step to reduce tension, both Pyongyang and Washington need to seriously consider the 'two suspension' proposal-Pyongyang suspending its nuclear and long-range missile tests in exchange for the suspension of joint military exercises or other shows of force game targeting Pyongyang by Washington and its allies.

In order to inject new momentum to reverse the downward security trajectory on the Korean peninsula and defuse the North Korean nuclear crisis, enhanced collaboration and concerted efforts are desperately needed between and among key players, including China, Russia and the United States. Innovative ideas should be encouraged, such as the proposal of a joint security assurance from Beijing, Moscow and Washington to Pyongyang in return for it freezing and final quitting production of nuclear weapons.

Neither single-handed pressure nor fragmented and disintegrated incentives will work. Given the seriousness and increasing urgency of the crisis surrounding the Korean peninsula, all concerned parties should step up their risk-reduction efforts before it is too late. EAFQ

\section{Chen Dongxiao is President of} Shanghai Institutes for International Studies. 
KRISTIN VEKASI

D ROTESTS broke out in more than 200 Chinese cities after the nationalisation of the Senkaku/ Diaoyu islands in 2012. Toyota saw sales plummet and vehicles smashed in street demonstrations. One of the company's responses was seldom talked about publicly but may prove to have long-term implications for the Japan-China relationship-it funded an exchange program that brought young Chinese students to Japan.

'Cold politics, hot economics' is a phrase used to describe the JapanChina relationship - on the one hand, their political interactions are tense, but on the other, their economic dealings are robust. In the aftermath of political disputes-whether they are sparked by territorial issues or prime ministerial visits to Yasukuni ShrineJapanese firms in China often face boycotts, property damage, exclusion from meetings and cancelled business trips. The environment for conducting business deteriorates.

Though political tensions are largely generated at the state level, there are implications for the private sector, most often felt on the Chinese mainland itself. Chinese citizens participate in boycotts and demonstrations. Chinese managers decide whether or not to work with a Japanese firm. Chinese consumers decide whether to purchase a Japanese automobile. In the face of these challenges, firms adopt riskmanagement techniques to help them operate in an often challenging Chinese society.

Corporate social responsibility activities are strategies used by Japanese firms to counter the negative consequences of antiJapanese nationalism in China. They include local health, education and environmental initiatives, but also social and cultural programs designed to foster pro-Japanese sentiment in China and, not surprisingly, among Chinese consumers. Corporate social responsibility activities that focus on social change include educational and cultural exchange programs which mirror 'heart-to-heart' diplomacy efforts and can be likened to the soft power initiatives used by diplomats. Firms invest their money in social and cultural activities in China with the goal of improving Japan's image and increasing their bottom line.

\section{Firms attempt to shape}

certain attitudes in

Chinese society to create

a business environment

that is more hospitable to their interests
A student exchange program run by the Japanese Chamber of Commerce and Industry in Beijing, known as 'Experience Japanese companies; Come close to Japan' shows the benefits of corporate social responsibility activities. The program was born shortly after 2005, a period in which Japanese companies were facing a fierce anti-Japanese backlash.

Around 100 companies donated a total of just over 200 million yen (US\$1.8 million) to bring young Chinese men and women to Japan on exchange trips. Toyota alone donated 100 million yen (US\$907,000). Remarkably, even after the fishing boat incident around the disputed Senkaku/ Diaoyu Islands in 2010, the program continued, though similar statesponsored programs were cancelled.

The program continued after the islands' nationalisation in 2012, despite Japan-China relations remaining tense for more than a year. There was an additional round of private donations amounting to almost 200 million yen from 74 companies in 2012. The program continues today.

The firms that participate in or contribute to these programs are likely to have experienced nationalist anger that affected their business. Their investments do offer some insulation against the negative effects of geopolitics. For the firms that contributed most, the chance of being targeted in 2012 versus 2005 fell by 40 per cent-though the program is of course only one factor of many that contributed to this outcome. With only 


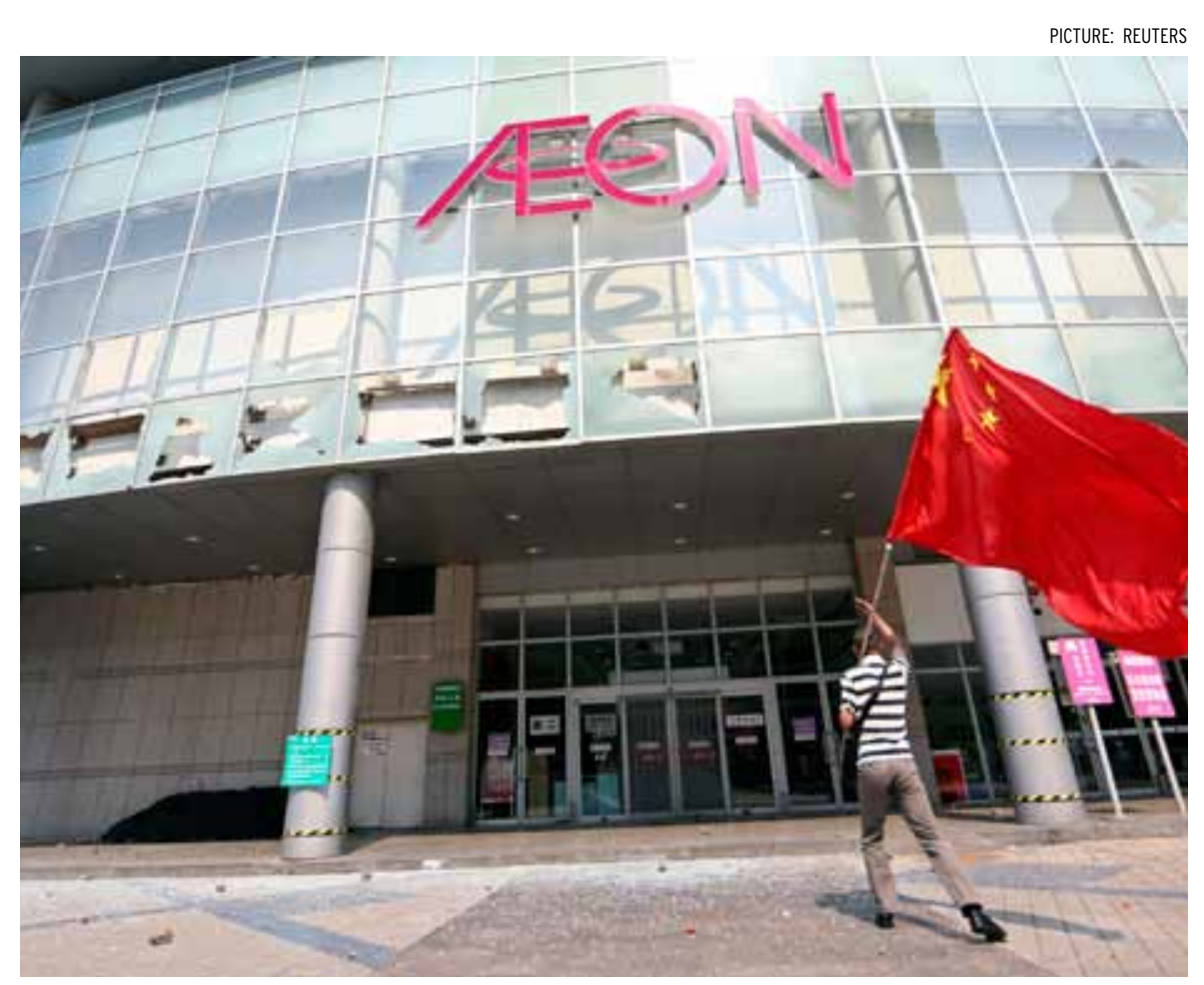

A flag-waving demonstrator outside the shattered facade of a Japanese-backed shopping centre in Qingdao. Japanese firms hope that social responsibility programs can improve Chinese perceptions.

two exceptions, these firms continued to donate in the second round of fundraising, indicating confidence in the program's effectiveness.

Chinese participants in the program also emerged with more positive views of Japan. The chamber of commerce reports that 'among participating students, quite a few went on to work in Japanese corporations or Chinese companies operating in Japan, and in the process further promoted friendly exchanges between the two countries'.

Firms attempt to shape certain attitudes in Chinese society to create a business environment that is more hospitable to their interests. By promoting a positive image of contemporary Japan and separating the image of Japanese society and business from its history or elite politics, they hope to soften anti-Japanese sentiment. When the Japanese government decides to increase its security presence around the Senkaku/Diaoyu islands, retailer Ito-Yokado does not want to have to deal with anti-Japanese demonstrations or property destruction. When a new history textbook is approved that plays down Japan's imperialist past, Japan Airlines does not want to see its ticket sales plummet.

Firms have long used corporate social responsibility instrumentally to mitigate business risks and as reputational insurance against labour, environmental, legal, or other crises. Members of the business community in Japan have suggested that contributing to Chinese society in this way is the most important strategy for firms because it addresses the overall problem of Japan's poor image in China, rather than simply treating the smaller symptoms. Anime exhibits, Japanese-language competitions, or programs like that of the chamber of commerce seek to present a Japan that is broadly appealing and distant from geopolitical rivalry or conflict.

Social strategies by firms represent a set of non-economic measures to protect their economic interests and are political in their consequencesthe firms are not only providers of commercial products or employment opportunities, but also merchants of their home country. They are drivers of informal public diplomacy, funded by the private sector. As Japan moves to play a more active security role in East Asia, its highly globalised firms will need to accelerate their efforts to insulate themselves from politics and promote the best aspects of Japanese culture and society.

Japanese firms are not alone in being targeted for the behaviour of their home government. With the rapid expansion of foreign direct investment globally, host governments and societies hold companies responsible not only for economic or business behaviour, but also for the policies endorsed by their country of origin. In East Asia today, South Korean companies in China are experiencing economic retaliation and discrimination following the deployment of the THAAD antimissile system.

The lessons to take away from the public diplomacy efforts of the Japanese private sector extend beyond the Japan-China relations. While it is not the duty of the private sector to undertake public diplomacy, multinational firms may find it prudent to sell softer and kinder versions of their home country to countries with which they seek to do business. EAFQ

\section{Kristin Vekasi is Assistant Professor in the Department of Political Science and School of Policy and International Affairs at the University of Maine.}




\section{The costs of constitutional reform in Japan}

\section{YUKI TATSUMI}

\section{ONSTITUTIONAL revision}

has always been a top priority for Prime Minister Shinzo Abe throughout his political career. Abe has consistently focused on revising Article 9 of the constitution in a way that would allow Japan to exercise the right of collective self-defence. This has been very important to Abe because he feels the existing provision continues to bring into question the constitutionality of the Japan SelfDefense Force (JSDF) and the kinds of activities in which the JSDF is allowed to engage.

By renouncing the right to belligerency and prohibiting Japan from possessing 'land, sea, and air forces, as well as other war potential', Article 9 has imposed heavy constraints on the way in which the Japanese government can use the JSDF. A very divisive debate emerges whenever the JSDF tries to do something-anything_-at home or abroad beyond a limited remit.

This debate has been particularly contentious whenever it involves issues surrounding Japan's selfimposed ban on exercising the right of collective self-defence (shüdanteki jiei ken). Simply put, a country's right of collective self-defence is its prerogative to consider that 'an attack on one is an attack on all' (in respect of its allies) and respond accordingly, including through the use of military force. Because the Japanese government long considered this right to be something

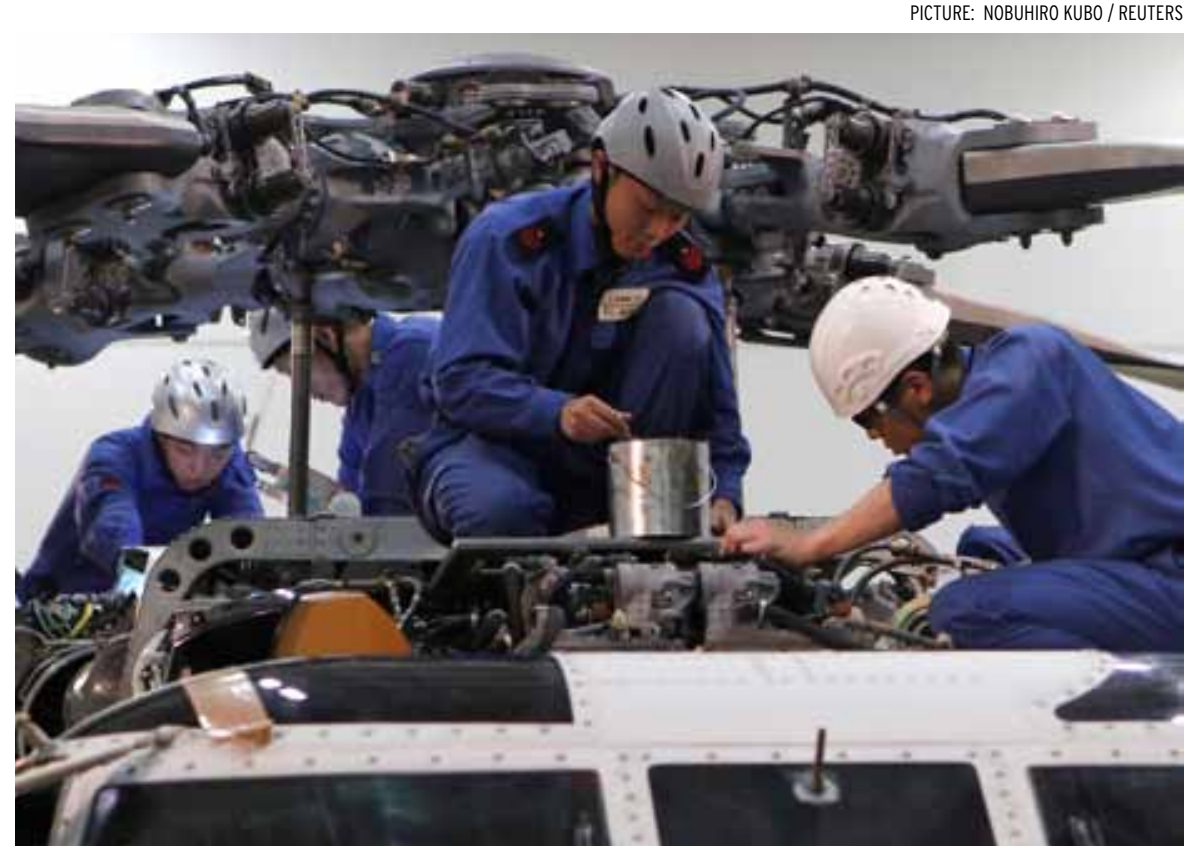

Japan Maritime Self-Defense Force technicians carry out maintenance on a Seahawk aboard the helicopter carrier Izumo in June 2017. Could constitutional change restrict the roles that Japan's forces are already authorised to undertake?

Japan possesses but cannot exercise, the JSDF's ability to co-operate with other countries' militaries has been limited.

Abe has been a strong advocate for revising Article 9 in a way that would allow the JSDF greater flexibility in its operations, including relaxing the severe restriction imposed by the ban on the right of collective self-defence. When he first served as Japan's prime minster between 2006-2007, Abe convened an advisory panelcommonly referred to as the Yanai Commission-which recommended 'four scenarios' under which Japan should be allowed to exercise that right. But Abe had already stepped down by the time the panel issued its interim recommendations in April
2008 and no further action was taken on them by his successors.

Abe picked up this issue again when he returned to power in December 2012. When asked about constitutional revision in his first press conference, in December 2012, he made specific reference to the recommendations submitted by the 2006 advisory panel and expressed his desire to reexamine them with renewed vigour.

Since then Abe has taken steady steps to move constitutional revision forward. To lay the groundwork for revision, he restarted the Yanai Commission's deliberations. The commission issued its final report in May 2014 and recommended that the ban on the right to exercise collective self-defence be lifted. In response, the 
Abe administration issued a cabinet decision ruling that Japan can exercise its right to collective self-defence under a limited set of circumstances. It passed a legislative package-the Peace and Security Legislation-expanding the scope of the JSDF's authorised activities which went into force in March 2016. Now Abe is eyeing submitting the constitutional revision draft to the autumn 2017 Diet session.

Abe's strong desire for constitutional revision, backed by the decisions he has made since December 2012, have come at a cost. Most obviously, Abe's decision to put his political capital into pushing this issue forward has left other pressing domestic issues unattended. From economic revitalisation to tax reform, pension reform, care of the elderly and promoting gender equalityincluding support for two-workingparent households-Abe has launched a number of initiatives with much fanfare. But few concrete results can be identified.

In particular, reform of the tax system, as well as pensions, health care and other entitlement programs urgently require the government's attention. These systems were created when Japan had a growing population and healthy birth rate. As society continues to age-close to 40 per cent of the population will be 65 years or older by 2065-these systems will become fiscally unsustainable if they are not restructured, particularly given the government's already heavy debt burden.

But reforming any of these systems is politically difficult. Reform inevitably means either raising taxes, cutting back on entitlement programs, or a combination of both. By choosing to spend his political capital on the national security agenda, including constitutional revision, Abe has largely passed responsibility for finding the solutions to these highly complex problems to his successors.

Less obvious but more important is the approach Abe took to push his agenda. He haas taken full advantage of the majority his Liberal Democratic Party (LDP)-Komeito ruling coalition maintains in both houses of the Japanese Diet to approve politically controversial bills, including the Peace and Security Legislation and one recent anti-conspiracy law. This has hardened the attitudes of opposition parties. As a result, debate on national security issues on the Diet floor has turned into verbal sparring between the two sides over what is legal and what is illegal, leaving other fundamental issues undiscussed.

Issues such as how far Japan is willing to leverage the deployment of the JSDF to achieve its national security policy goals vis-à-vis other countries, and how elected leaders can maintain civilian control of the military (JSDF) while ensuring the JSDF's political neutrality, were hardly discussed on the Diet floor. Unless Abe dramatically changes his approach when his government submits the draft proposal to revise the constitution, it is hard to see a thoughtful debate on any of these issues taking place in the Diet this time

\section{Abe's decision to put}

his political capital

into pushing this issue

forward has left other

pressing domestic issues

unattended around.

Abe's obsession with making the JSDF a constitutional entity by revising Article 9 may also force his successors to engage in increasingly complicated verbal contortions to justify JSDF activities. Hoping to gain support from those unsure about revision, Abe currently proposes to amend Article 9 by adding a clause explicitly defining the JSDF as an 'organisation for national defence.' But doing so without amending other clauses would continue to force the government to justify the JSDF as 'an organisation for national defence' that is not land, naval or air forces. This could be more restrictive than what the JSDF is already authorised to do, especially overseas.

Although the Abe government's support rate improved after the cabinet reshuffle on 3 August, many opinion polls, including those by Yomiuri Shimbun, still indicate an overall trend of fewer people supporting the cabinet. Any constitutional revision Abe tries to push will likely come at a cost.

The constitutional change that Abe is eyeing is likely to mean that even after such revision, a continuing lack of consensus on how Japan should use the JSDF, persistent sharp political divisions over this issue, and lack of thoughtful debate on national security issues in the Diet will persist. It also means that it will come at the cost of the government's ability to address more pressing issues that have a real impact on Japanese people, with very little actual change. EAFQ

Yuki Tatsumi is the Director of the Japan Program at Stimson Center in Washington, DC. She also concurrently serves as non-resident Senior Fellow at Canon Institute for Global Studies in Tokyo. 


\section{Can Japan accept itself as a nation of immigrants?}

ERIKO SUZUKI

4 MMIGRANTS' is a word more commonly heard in Japan in recent years. One reason for this is the need to respond to the country's shrinking population. As of 1 October 2016, Japan's total population was estimated to have dropped for the sixth straight year. The rate of population decline has also grown consecutively for each of those six years. The share of elderly people in Japan's population is the highest in the world, and is increasing at a pace seen nowhere else.

The National Institute of Population and Social Security Research (IPSS) estimates that in the year 2040, the total population of Japan will be 110.92 million compared with roughly 126 million today. Of this total, the productive population, those aged 15-64, will account for 59.78 million and those aged 65 and over will account for 35.3 per cent. The IPSS estimates that in 2065 , these figures will be 88.08 million, 45.29 million and 38.4 per cent, respectively.

It may be unrealistic to suggest that Japan 'replace' its declining population and labour shortage solely through migration. But if depopulation is set to harm Japanese society, it is only natural to start considering increasing immigration.

Since Prime Minister Shinzo Abe took back the reins of government in December 2012 and began promoting his Abenomics growth strategy, depopulation has come under the spotlight as a key ‘problem' for Japan.
To achieve sustainable development even with population decline, women, elderly people and young people would all be called on to mobilise. Within this context 'utilising foreign human resources' has been promoted and related policies quickly implemented.

The government has expanded its acceptance of foreign national 'rotation-type' labourers-that is, unaccompanied workers who have a maximum limit on how long they can stay in Japan. But whether this is the appropriate way to address the current situation is highly questionable.

Rotation-type workers may be able to alleviate short-term labour shortages but they cannot be expected to curb depopulation trends in the mid to long term.

Though the acceptance of more immigrants has previously been discussed in a government committee, in June 2014 the Abe cabinet made clear that 'utilising foreign human resources' was 'not an immigration policy'. Instead, Japan would aspire to 'stabilise its population at around 100 million in fifty years' without relying on immigrants.

To achieve that goal, government projections indicate that the total fertility rate (or births per woman) would have to reach a rate of about 1.8 in 2030 and 2.07 (the rate at which the population can replace itself) in 2040. The real fertility rate in 2016 was just 1.44 .

We may admire any plan to improve the social environment so that those who wish to bear and raise children can do so, but such a substantial change in the total fertility rate will undoubtedly be incredibly tough to realise.

Migration may present the solution. Still, it must be asked: don't immigrants already exist in Japan?

What constitutes an 'immigrant' has not been clearly defined. But for argument's sake, 'immigrants' can be defined as 'settlement-type' foreign nationals who are able to settle in Japan and have a family, with the capacity to extend their period of stay or to change their residential status. This is opposed to the less secure conditions faced by rotationtype foreign workers. As of the end of 2016, more than 80 per cent of the $2,382,822$ foreign nationals in Japan were 'immigrants', and 44.7 per cent had permanent residency.

$\mathbf{T}$ HE population share of foreign nationals in all of Japan is 1.88 per cent, a low figure compared with industrialised Western nations. But according to population indicators in the national census, while the total population of Japanese nationals declined by 0.9 per cent between 2000 and 2015, the number of foreign nationals increased by 33.7 per cent in the same period.

Despite the decreasing overall population in Japan, the 'social population'-the number of people moving to and from Japan-has continued to rise for four consecutive years because of the increase in foreign residents. Regardless of 


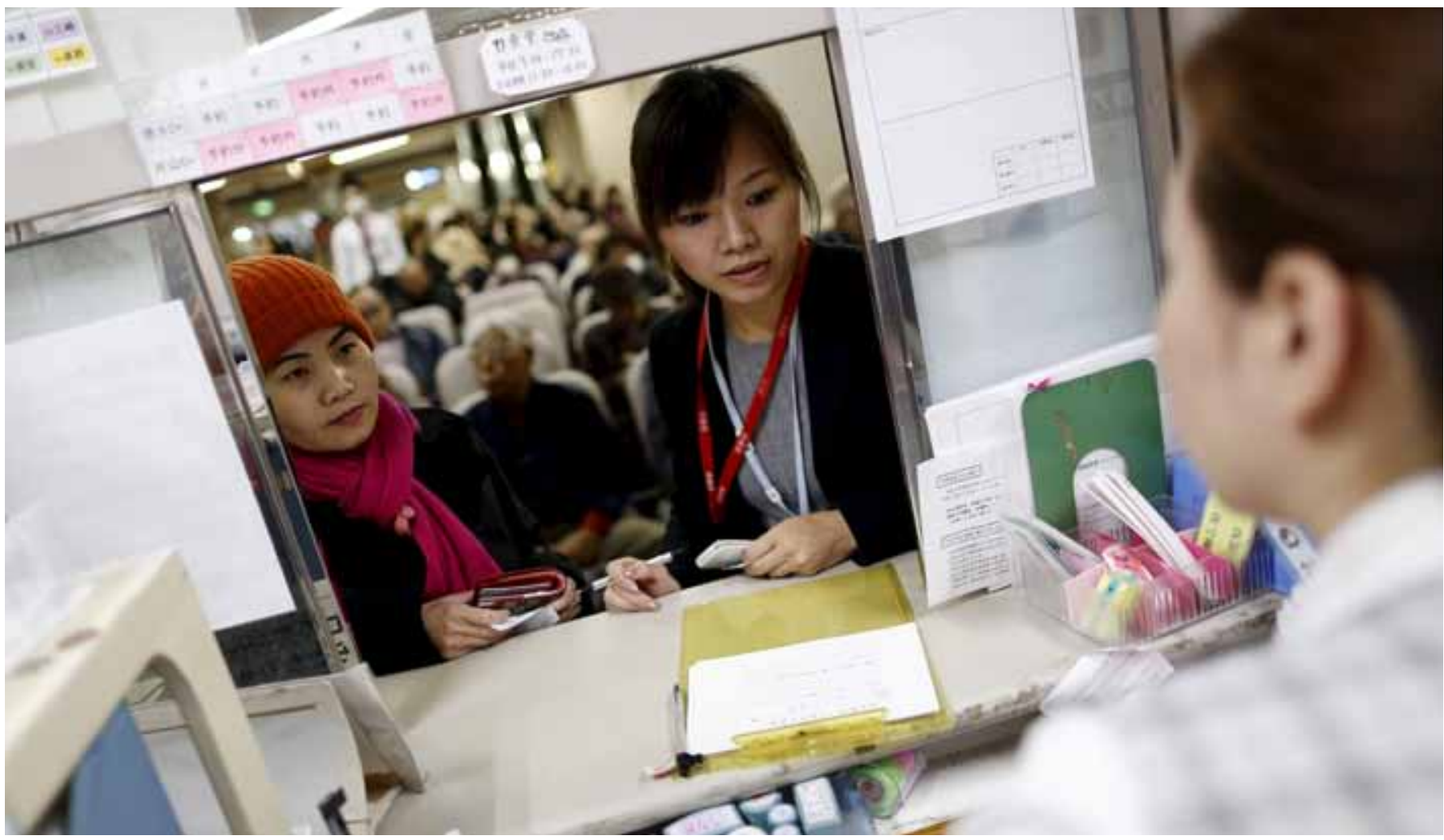

Dang Nguyen Thuc Vien, centre, the daughter of refugees from South Vietnam, interprets for a local Vietnamese resident at a hospital in Kanagawa prefecture, south of Tokyo. What constitutes an 'immigrant' in Japan 'has not been clearly defined'.

whether the government is accepting foreign nationals under an intentional population-based policy, the reality is that immigrants are already putting the brakes on depopulation.

It is also not uncommon for many Japanese citizens to have immigrant backgrounds, such as former foreigners who have acquired Japanese nationality and Japanese nationals who have been born to a Japanese national and a citizen of another country. Today, we see their accomplishments in a wide range of areas, including sports, culture and academia. Even looking back at Japan historically, it was not an ethnically homogenous nation.

If the government was wise, it would have already recognised the existence of immigrants in Japan and the fact that, to secure the long-term sustainability of Japanese society, we cannot go on without relying on more immigration. Why, then, does the government continue to turn a blind eye to the very existence of immigrants in Japan?

Is it because the government is fixated on narrow-minded nationalism, and worries about the riots involving immigrants, antiimmigrant movements and the divisions emerging in societies across the West as 'failures' of immigration policies?

C ONSIDERING the serious state of depopulation that Japan now faces, putting off the debate on immigration is not a wise choice. Denying that certain moves made by the government are a part of its immigration policy delays the drafting and implementation of integration policy for immigrants who already live and work in Japan. It also hinders the institutional and psychological preparation necessary to provide an environment in which new immigrants can be accepted into Japanese society.

It is important that Japan cultivate a constructive forum for national debate on accepting immigrants by overcoming the government's deceit that 'utilising foreign human resources' is 'not immigration policy'. The government must be conscious of our responsibilities to future generations and recognise the diversity that immigrants have brought to Japanese society, without seeing their function as mere quantitative replacements for Japanese people. EAFQ

Eriko Suzuki is Professor, Faculty of Letters, Kokushikan University in Tokyo. 


\section{CURRENTS OF THE TIMES}

\section{Trump enamoured by an Abe charm offensive}

GERALD CURTIS

J APANESE Prime Minister Shinzo Abe's courting of Donald Trump, so far at least, has been a political success for Japan and for Abe's style of personal diplomacy.

Abe moved with impressive speed to get on Trump's good side as soon as the US election results were in. He called him the following day and visited him at Trump Tower 10 days later, determined to establish a personal relationship with an incoming president whom neither he nor anyone else in Japan's leadership circles knew well, if at all.

During their Trump Tower conversation the two leaders seem to have bonded, chatting for an hour and a half, 30 minutes longer than had been scheduled. When Abe exited Trump Tower he told the waiting Japanese press corps that the conversation convinced him that Trump 'is a leader I can trust.'

Abe arrived in Washington in early February 2017, the second foreign leader after UK Prime Minister Theresa May to have a summit with the newly inaugurated President and the first to be invited to ride with him on Air Force One to Florida for a weekend at his Mar-a-Lago resort. Twenty-seven holes of golf, lunches and dinner gave Abe ample opportunity to share his views with Trump. All indications are that Abe did most of the talking-about China, North Korea, Japan's defence policy, and how investments by Japanese corporations in the United States had created hundreds of thousands of jobs for US workers.

Abe's charm offensive appears to have paid large dividends. Trump found in Abe the leader of an important allied nation who was not criticising his immigration policy or his desire to develop a personal rapport with Vladimir Putin, and whose enthusiasm for working closely with Trump seemed genuine. There was not anything Trump said to the press or that was in the leaders' joint communiqué that echoed the critical views he had voiced about Japan during the campaign.

Abe set out for Washington and Mar-a-Lago intent on accomplishing what every Japanese prime minister since the end of World War II has understood to be the most vital task of Japanese foreign policy: to ensure the stability of the US-Japan alliance.

During the eight years of the Obama administration Abe emphasised the shared US and Japanese commitment to values of democracy, freedom and human rights, and to sustaining a liberal international order and strong multilateral institutions. But that was then.

Japanese heaved a

collective sigh of relief

when Abe returned

home unscathed from his

summit with Trump
Now the United States has elected a president who has said that he rejects the central role the United States has played in maintaining the postwar international order in favour of an 'America First' foreign policy. Abe lost no time to adjust his rhetoric and his strategy to meet the new situation.

Abe's actions underscore the reality that when it comes to protecting its national security, Japan has no option but to do whatever it takes to forge a close relationship with the US president, whoever she or he might be. This is also a useful reminder of how different the situation faced by Japan is compared with that of the United States' European allies.

Germany sits inside the EU which, whatever its problems, is a community of (mostly) like-minded states. The United Kingdom after Brexit will no longer be part of the EU but its people will continue to live in a region of economically advanced and democratic states.

Japan by contrast is an outlier in its region, a democracy that counts among its closest neighbours three autocracies (or worse): China, North Korea and Russia. All are nuclear weapons states. Its other close neighbour, South Korea, is a democracy, but its relations with Japan are strained by tensions emanating from the history of Japanese colonisation.

The most important challenges facing the United States and Japan are not how to manage the bilateral relationship but rather how to coordinate policies to deal with North 


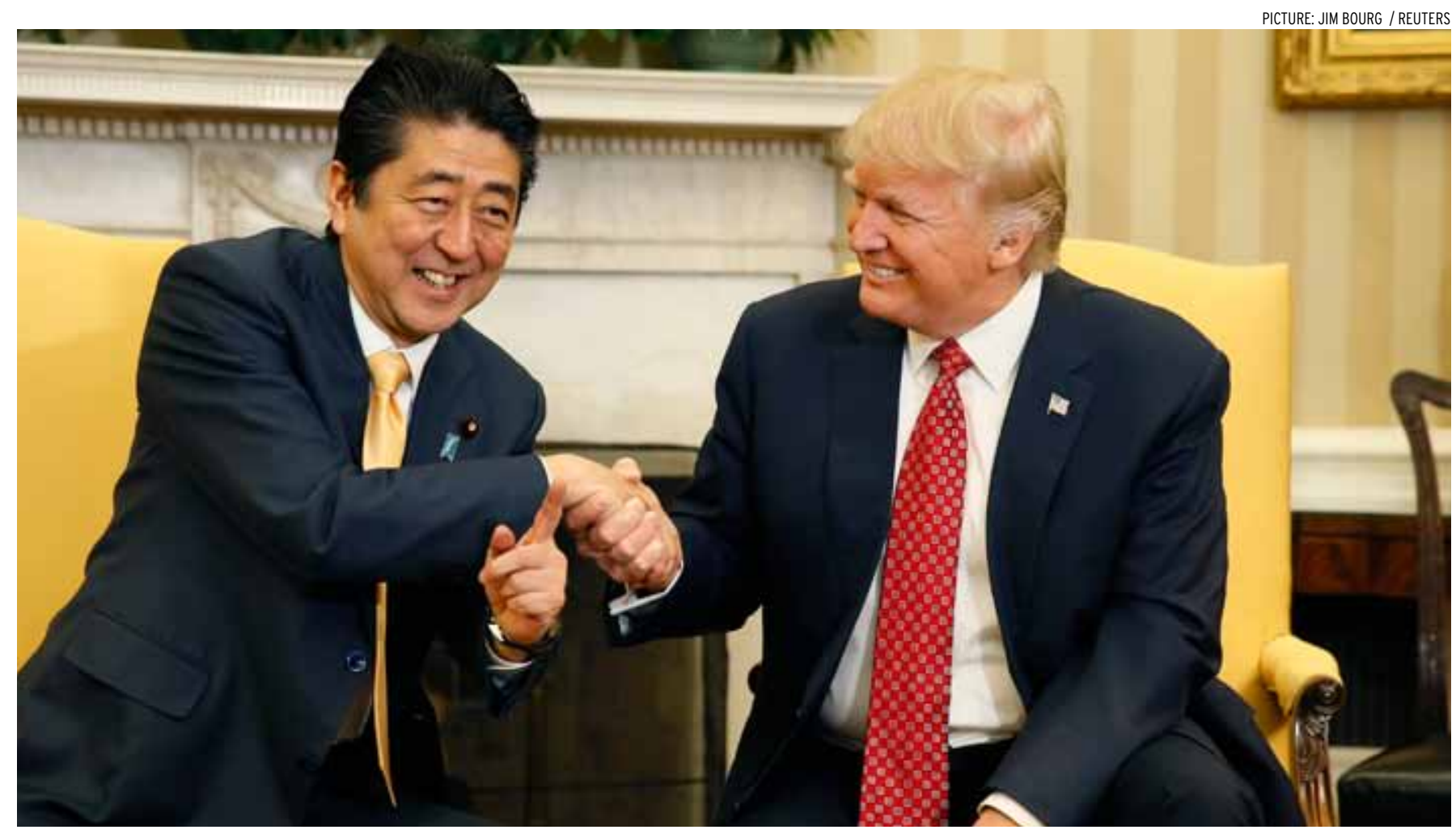

All smiles: Japanese Prime Minister Shinzo Abe and US President Donald Trump at their meeting in the Oval Office in February 2017.

Korea's nuclear quest, China's activities in the East China and South China seas, and changes taking place in the global economy. Japanese heaved a collective sigh of relief when Abe returned home unscathed from his summit with Trump. But there is little comfort to be taken in knowing that the bilateral relationship is basically in good shape if the world around it is in turmoil. That turmoil shows no sign of quieting down.

Abe has responded to this situation with the kind of flexibility that has been characteristic of his years in office and that few of his critics expected when he became prime minister for the second time in 2012. He has not gone back to Yasukuni Shrine since his 2013 visit, which triggered strong criticism from Beijing and Seoul and drew an admonition from a 'disappointed' United States. He has backed away from his earlier support for a major revision of the controversial Article 9 of Japan's constitution, and from the position taken by the governing Liberal Democratic Party in its 2012 constitutional revision draft. His proposal now is to keep the existing two clauses in Article 9 as they are and add a third recognising the legality of the Self-Defense Forces.

Well aware that the alliance with the United States is essential to maintaining a balance of power in East Asia, Abe has been careful not to say anything to offend Trump. But he is not putting all of Japan's eggs in the US basket. Strengthening security relations with Australia, Southeast Asia and India, siding with the United States' European allies on the Paris climate accord, seeking an agreement with Russia on the contested northern islands issue, and most recently signalling to China Japan's interest in participating in the Belt and Road Initiative are part of a broad-based strategy to secure Japan's interests in an increasingly uncertain international environment.

Japan's foreign policy since Commodore Perry's black ships entered Tokyo Bay in 1853 has been guided by a determination to keep in step with the 'currents of the times'. Now that Trump is in office it is unclear where those currents are leading. Abe has succeeded in getting Trump to drop his campaign rhetoric about Japan and has gotten their relationship off to a good start. But from what we have seen of the way Trump treats allies and disparages international agreements and institutions it would be foolish to believe that they necessarily will remain on an even keel, or to assume that Abe thinks they will. EAFQ

Gerald Curtis is Burgess Professor Emeritus of Political Science at Columbia University. 


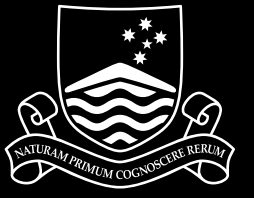

Australian

National

University

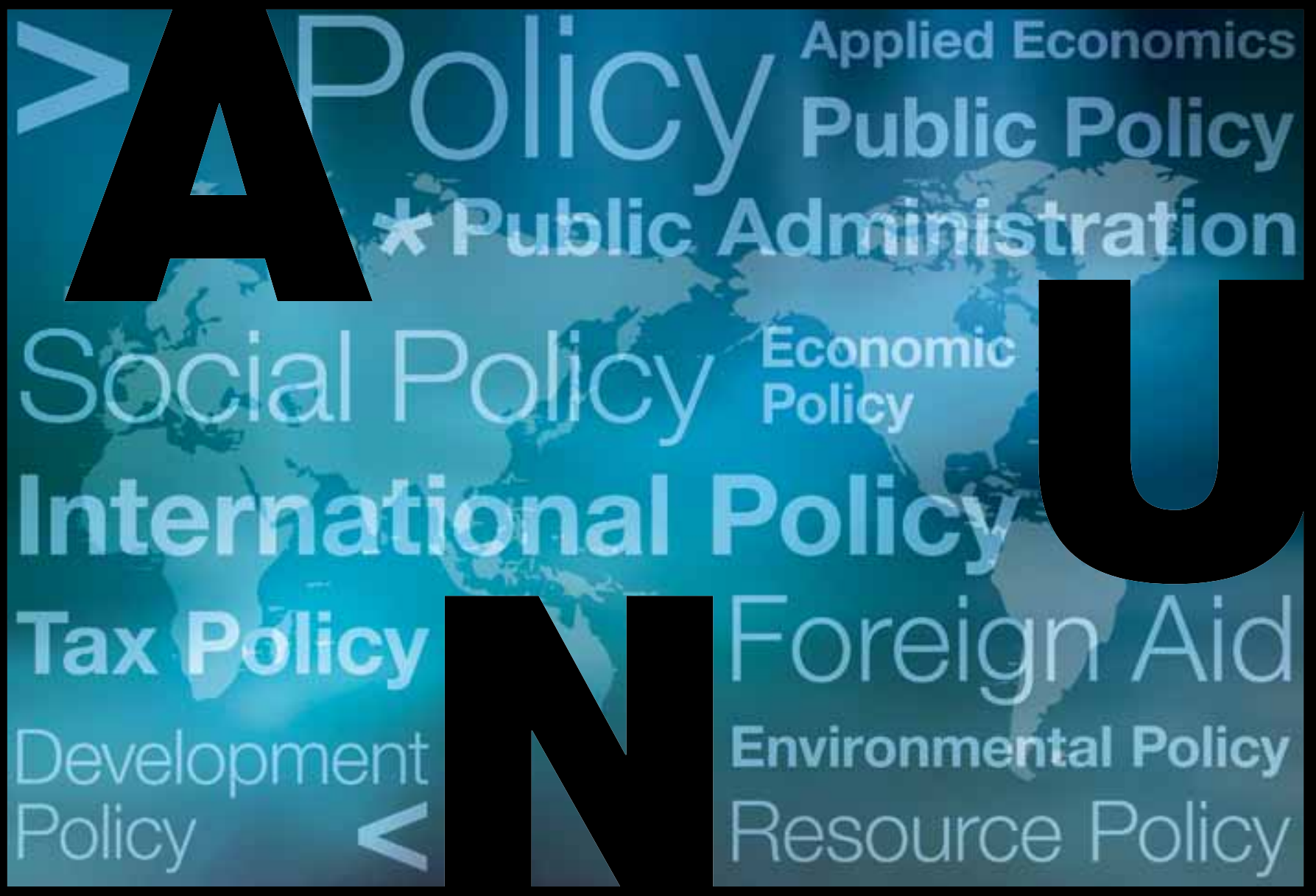

\section{INFLUENCE THE REGION'S FUTURE}

Be part of Asia's economic integration

\section{Join our international public policy community.}

crawford.anu.edu.au

Crawford School of

Public Policy

ANU College of

Asia \& the Pacific 